Proceedings of the Prehistoric Society 78, 2011, pp. 51-71

\title{
Excavations in the Acheulean Levels at the Earlier Stone Age Site of Canteen Koppie, Northern Province, South Africa
}

\author{
By JOHN MCNABB ${ }^{1}$ and PETER BEAUMONT ${ }^{2}$
}

The fluvial gravels of the river Vaal in South Africa have long been known as a source for Earlier Stone Age (ESA) artefacts. Most were discovered through the open cast mining for diamonds that has left very little in situ fluvial sediment remaining today. The site of Canteen Koppie is an internationally famous location with a reputation for prolific Acheulean artefacts, especially handaxes and the enigmatic prepared core and Levallois-like technology known as Victoria West. Our understanding of this site, and most other Vaal locations, is almost solely based on highly selected artefact collections. Here, we report on the first controlled excavations ever to be conducted at Canteen Koppie. The deposits are likely to date to the Early and Middle Pleistocene, and our excavations sample the full depth of the stratigraphic sequence. The lower units, first identified in these excavations, add a considerable time depth to the Acheulean occupation of the site, making this the longest chrono-stratigraphic sequence in South Africa to our knowledge. Given the current international interest in the origins of Levallois/prepared core technology (PCT), its occurrence in Unit $2 b$ Upper, and its presence alongside Victoria West technology in Unit 2 a has significant implications for debates on the role of Victoria West in the origins of PCT. From the Canteen Koppie evidence, Levallois and Victoria West are clearly rooted in the Acheulean.

There has been a recent resurgence of interest in the Acheulean and its technological character in Africa and elsewhere (Beaumont \& Vogel 2006; Sharon 2007). In South Africa, a significant contribution to this has been the recognition of deeply stratified sequences within the Pleistocene gravels of the basin of the river Vaal (Fig. 1), a classic area for Acheulean studies (Van Riet Lowe 1935; 1937; 1952).

The Acheulean is a stone tool assemblage type whose earliest appearance is in Africa c. 1.7 million years ago (Semaw et al. 2009) and continues until $c$. 0.3/0.25 million years ago (Harris et al. 2007). During this period the Acheulean spread throughout much of the Old World carried by migrating hominins as part of their repertoire of adaptations to new environments and new circumstances. It is primarily identified on the presence of large cutting tools such as handaxes and

\footnotetext{
${ }^{1}$ Department of Archaeology, University of Southampton, Avenue Campus, Highfield Southampton SO17 1BF

${ }^{2}$ c/o McGregor Museum, PO Box 316, Kimberley, 8300, Northern Cape, Republic of South Africa
}

cleavers (see below) which were Acheulean innovations grafted on to a suite of core and flake tool types that had been present in the preceding Oldowan. But equally as important, and innovative, were technological advances that allowed for the production of large flakes (usually considered to be $>100 \mathrm{~mm}$ in length), as well as the preparation of cores in a variety of ways that would enable the detachment of such flakes. This combination represented the Acheulean package. Although Semaw et al. (2009) advocate caution, it is possible that the Acheulean package appears quite suddenly in the archaeological record and that these flake blanks are present from relatively early on in the Acheulean's history (ibid.). This large flake blank Acheulean (Sharon 2007), sometimes called the large flake Acheulean, can be seen throughout southern, northern, and eastern Africa, and in other areas of the Old World where flint and flint-like raw materials are uncommon.

The Victoria West phenomenon is a Levallois-like technology in that a preferentially conceived surface is created, from which a single flake is detached. The configuration of the preferential surface pre- 


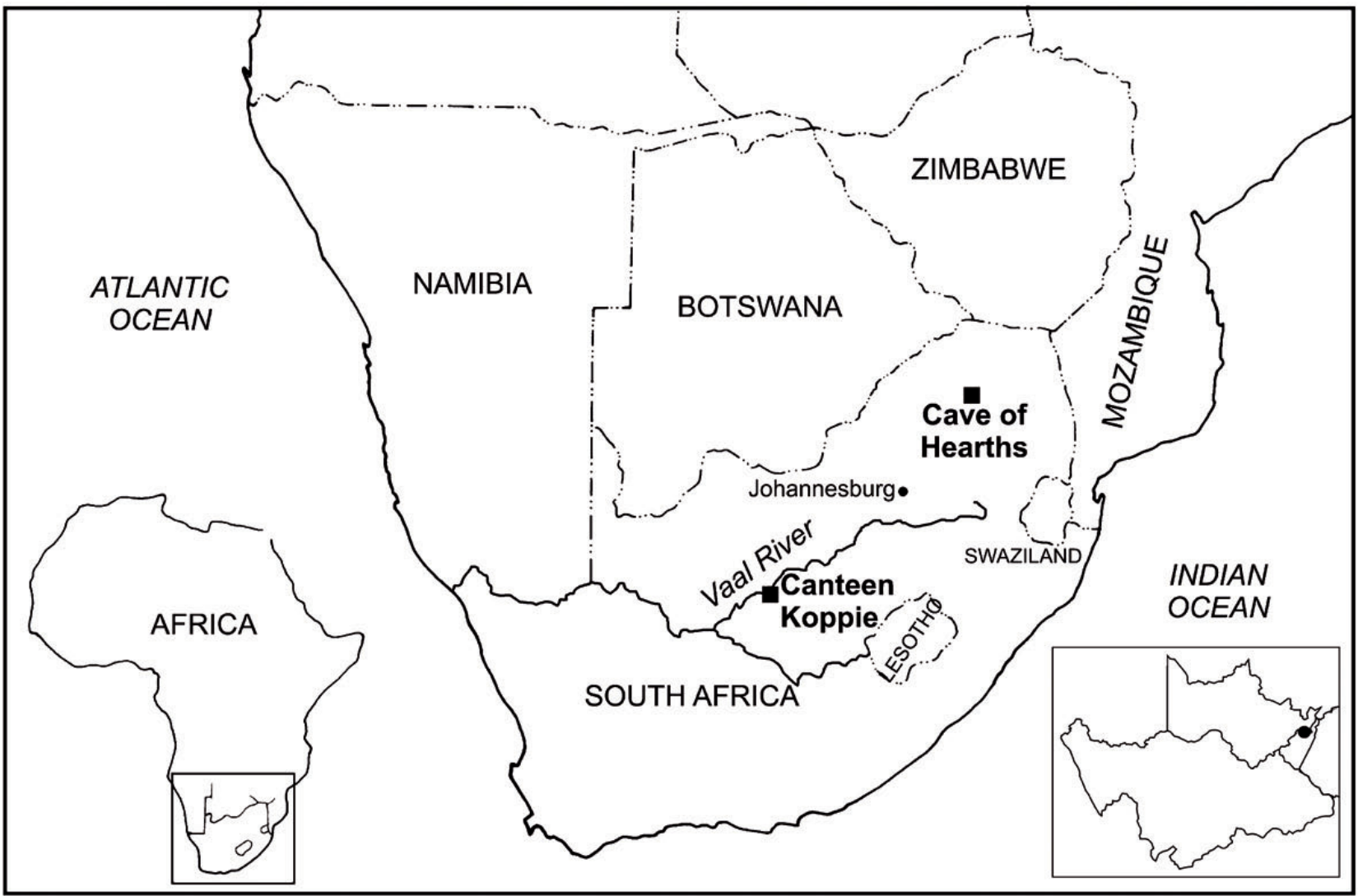

Fig. 1.

Map showing location of the site of Canteen Koppie on the river Vaal, Northern Cape, South Africa. Also shown is the location of the Cave of Hearths, Limpopo Province, South Africa. Box inset shows Northern Cape with Canteen Koppie and Kimberley (marked by dot) on the Vaal river flowing into the Orange river (main map drawn by Wendy Voorvelt)

determines to some extent the final form of the desired end product. Figure 2 shows a Victoria West core from a number of angles in order to illustrate the Levalloislike knapping involved. The flake-scar for the preferential flake can be clearly seen in Figure 2a and its concavity is equally clear on Figure $2 c$ as its preferential surface is being held. It is hardly surprising that, when first discovered, they were mistaken for handaxes. Ever since it was first recognised (Jansen 1926; Goodwin 1929; 1934) the relationship of the Victoria West to the Acheulean and to the Levallois which characterises the later Middle Stone Age (MSA) has been debated. This debate has not yet been resolved. The significance of the debate has broadened because Levallois has been linked to the migration of a putative modern human ancestor out of Africa (Foley \& Lahr 1997). Levallois is also linked to possible developments in cognitive or physical evolution (McBrearty \& Brooks 2000; Tryon \& McBrearty 2002) accompanying major behavioural changes in hominin lifestyles (Van Peer et al. 2003; Barham 2010). Victoria West has been seen as the beginning of unilinear technological evolution toward the Levallois of the MSA (Van Riet Lowe 1945; Rolland 1986). But positive proof of these claims remains to be found, and simple unilinear evolutionary schemes for material culture can be disputed (Tryon \& McBrearty 2002; Van Peer et al. 2003). Whether the Levallois is polygenetic (multiple chrono-spatially distinct origin points), or monogenetic (one single origin followed by continuous or punctuated dispersal) remains equally unclear (Rolland 1995).

So, the origin of Victoria West technology, and its true relationship with the Acheulean are key research 


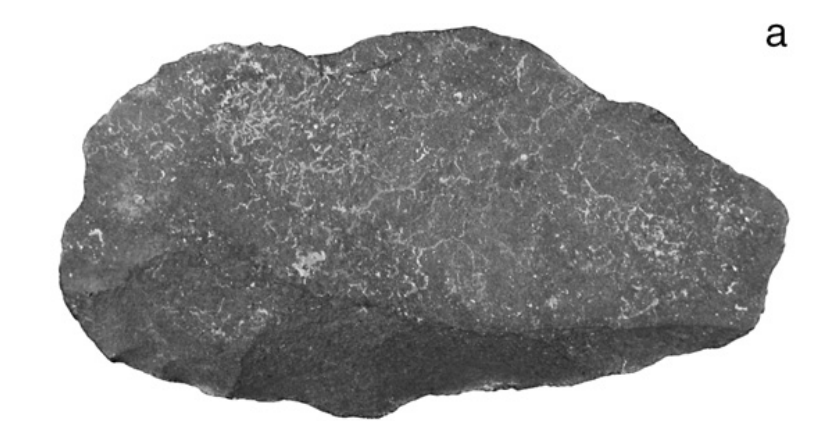

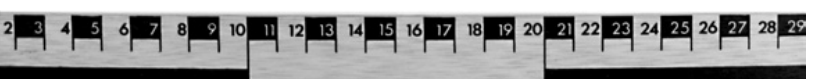

b
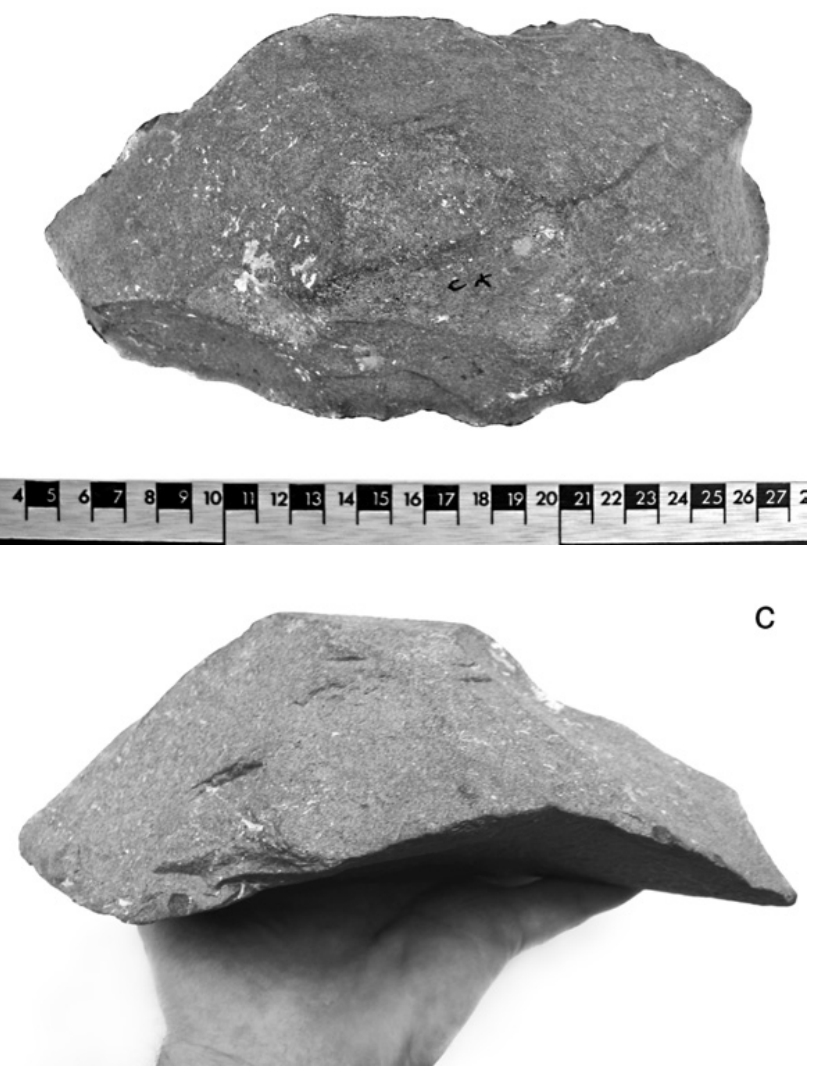

Fig. 2.

A classic example of a side-struck Victoria West core from Canteen Koppie (surface find): a) showing the large negative flake-scar bed after the removal of the preferential flake whose left hand side (in this view - proximal to the top) would have been wide and convex and whose right hand side would have tapered; b) under-side of the core; c) showing the core in profile with the underside of the core uppermost. The thickness of the preferential flake can be gauged from the depth of the concavity questions in themselves, but they also lie at the root of other significant research questions relating to later hominins and evolutionary advances. Canteen Koppie can provide important information on these issues.

Most historical surveys of the Earlier Stone Age in South Africa cite the seminal overview of Goodwin and Van Riet Lowe (Goodwin \& Van Riet Lowe 1929), which building on earlier work, cemented the use of the term Stellenbosch for the South African Acheulean. By the late 1920s it was recognised as being extensive throughout South Africa. Canteen Koppie was mentioned briefly as possessing a few heavily worn and rolled handaxes and cleavers. While Victoria West technology was first introduced into the archaeological literature in the mid-1920s (Jansen 1926), it was not until a field trip by members of the British Association for the Advancement of Science in 1929 that Victoria West artefacts were recognised at Canteen Koppie. A later visit that year confirmed their presence. Goodwin updated his 1929 cultural sequence in the early 1930s (Godwin 1934). Canteen Koppie was used to demonstrate that stages in the evolution of the Victoria West culture were contemporary with stages in the development of the Stellenbosch Acheulean. In an equally seminal contribution, Van Riet Lowe (1937) proposed that the Victoria West technology, and its developmental stages were part of the Stellenbosch/Acheulean's evolution because the flakes from the Victoria West cores were the blanks for cleavers and handaxes. It was between 1934 and 1937 that the richness of the site became apparent, and large collections of handaxes, cleavers, and Victoria West cores were crated up and dispatched to museums throughout Africa and Europe. More detailed summaries of the history of research along the Vaal are presented elsewhere (Helgren 1978; 1979; Beaumont \& Morris 1990; Beaumont 1999b; Morris \& Beaumont 2004; Kuman 2007; Wadley \& McNabb 2009).

With the exception of the Cave of Hearths (Mason 1959; 1962; 1988; McNabb \& Sinclair 2009), most interpretations of Acheulean culture in southern Africa made before the early 1960s, on open air sites, were based upon surface collections of stone tools and/or selected artefacts from small assemblages which gave a particularly slanted view of the evolution of the Acheulean in southern Africa (Van Riet Lowe 1952). Fieldwork by one of us (PB) at Canteen Koppie, and elsewhere along the Vaal (Beaumont \& Morris 1990; Beaumont 1999b; Beaumont \& Vogel 2006), has attempted to relocate what few extant sequences of 


\section{THE PREHISTORIC SOCIETY}

Pleistocene sediments remain undisturbed by the extensive diamond mining operations conducted up and down the banks of the Vaal for more than a century.

Papers by Sharon (Sharon \& Beaumont 2006; Sharon 2007; 2008; 2009), Gibbon and colleagues (2009), and Lycett (2009; 2010), amongst others, include Canteen Koppie in their discussions on Acheulean and Victoria West technology. However a full description of the stone tool assemblages from this site has never been published. Consequently, those aspects of the ESA artefact record at Canteen which are often taken out of their assemblage context, such as Victoria West technology or handaxes, etc, are studied without full understanding of their relationship to other aspects of the lithic record at the site. This serves to focus our attention on site context, assemblage context, and site interpretation. We believe that it is crucial to all future discussions of these points that the archaeology of Canteen Koppie be properly understood. In the confident expectation that the location will figure increasingly in new research, we believe it is essential that these data be available to students of the Acheulean.

This paper therefore provides an overview of the Acheulean stone tool assemblage from the excavations of one of us (PB) at Canteen Koppie. This was the first controlled excavation ever carried out at the site. The results of Beaumont's excavations are significant. They represent the only controlled excavation that samples the full depth of the Pleistocene gravels (nearly $9 \mathrm{~m}$ in Area 1), and contain the full stratigraphic profile observed at the site (Unit 1, Unit 2a, Unit 2b Upper \& Unit $2 b$ Lower). To the best of our knowledge this represents the deepest controlled excavation on an open air ESA site in South Africa, and represents the longest record of Acheulean technology at the southern tip of the African continent.

\section{THE GEOLOGICAL SEQUENCE AT THE SITE}

Classic descriptions of the sediments at Canteen Koppie (see Figs 3-5, were presented by Söhnge and Visser (Söhnge et al. 1937) and by later interpreters (Partridge and Brink 1967; Helgren 1978; 1979). Full summaries and overviews are provided by Helgren (1979) and de Wit (2008). Helgren (1979) renamed the Vaal's gravels giving them the status of a geological formation, the Rietputs Formation. Canteen Koppie was placed in the earliest member of the formation, the Rietputs A, with a possible Lower Pleistocene age. Beaumont disputed the fluvial character of the gravels at Canteen, believing them to be primarily colluvial, a theory first proposed by du Toit in the 1920s when many more sections were available than present day (Beaumont 1990; 1999a). Recent field work (de Wit 2008) combined with chrono-stratigraphic analysis (Gibbon et al. 2009) has materially contributed to our understanding of the stratigraphic context of the sediments at Canteen Koppie.

The basic sequence is presented in Figure 4 as a composite stratigraphic profile. This was constructed from the observed geological sequence at a number of locations (see Figs $3 \& 5$ ). It is important to note that in the recently published overview of the geology of Canteen Koppie by de Wit (2008), his units F-C equate with our Unit $2 \mathrm{~b}$ Lower (Fig. 4), and his B equates with our Unit $2 \mathrm{~b}$ Upper. In addition, his pit CK06 is the same as our Area 1, not to be confused with our Pit 6 on Figure 3 which is the site of renewed excavations by Kathleen Kuman, Ryan Gibbon, and George Leader.

Moving from the base of the sequence upwards (Fig. 4), Unit $2 \mathrm{~b}$ represent a series of fluvial gravel deposits in a sandy matrix. Erosion horizons in between subunits, and coarse cross-bedding, indicate that Unit $2 b$ Lower is a series of gravel bars (de Wit 2008). Their location was a result of the Vaal dropping its bed load at this point. It is postulated that a few hundred metres upstream of the site, the river flowed through a narrow defile formed between two koppies. This was a former channel of the Vaal now abandoned. On exiting from the narrow channel the bed load was deposited in a splay (ibid.), with the gravel bars forming a part of the splay's development. The whole depositional sequence at Canteen is interpreted as an upward coarsening profile (ibid.; however personal observation by one of us (JM) renders this unlikely; there were just as many large boulders at the base of Unit $2 b$ Lower as in Unit $2 \mathrm{a}$, they were just removed during the excavation and not present in the walls of the section later examined by de Wit). The upward coarsening of the deposits suggested to de Wit that over time there was an increasing scree component to the fluvial composition of the gravel bars. This scree was deposited by gravity from the slopes of the adjacent koppies. Consequently, Unit 2a (unit A of de Wit) is a massive andesite gravel, a result of significant scree accumulation from the nearby slopes. However, de Wit asserts that the river 


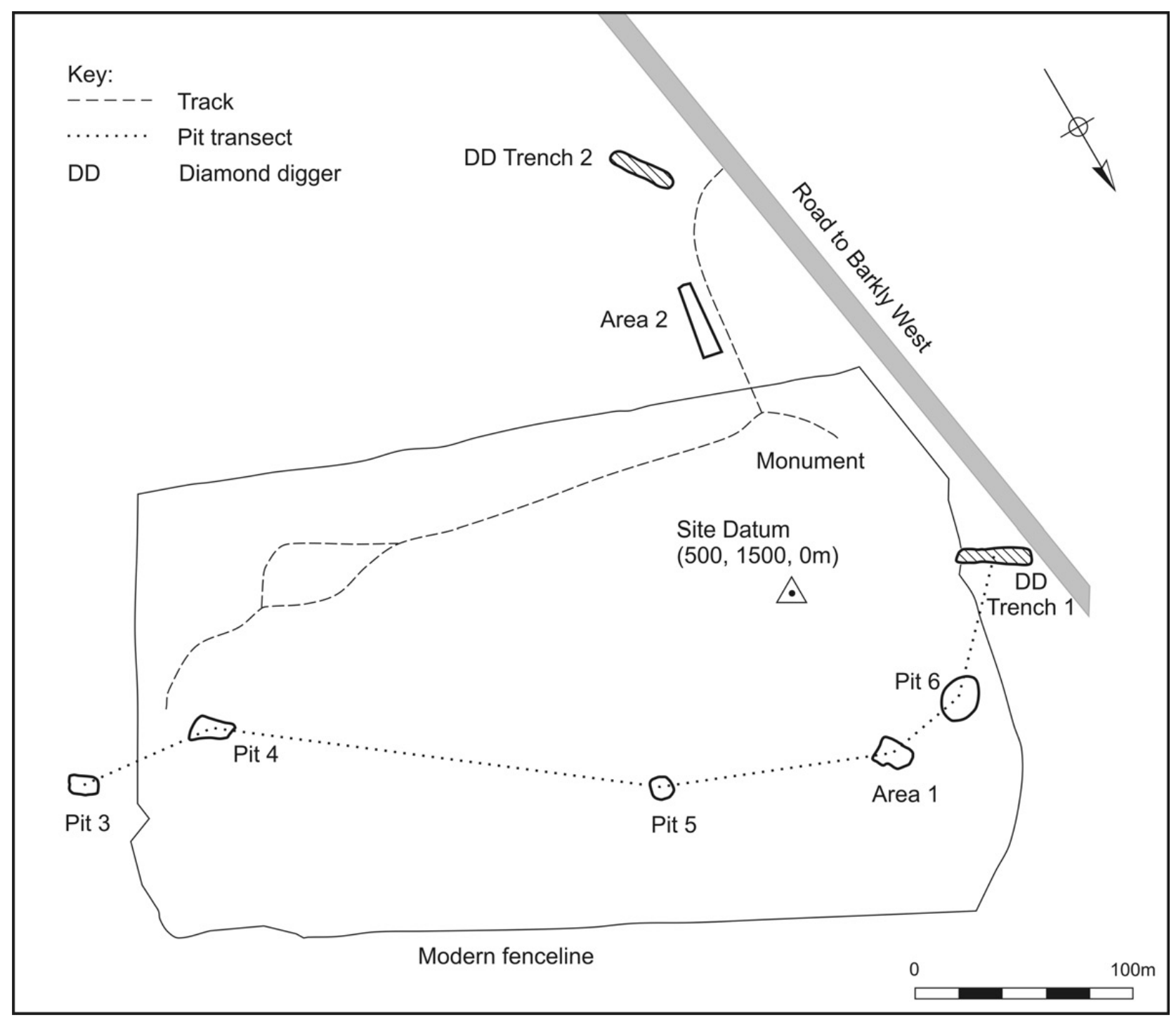

Fig. 3.

Site plan of Canteen Koppie. The fence line marks the boundary of the national monument within which the sediments and archaeology are protected by statute

was still using this palaeochannel because there is evidence of intermittent fluvial resorting of the gravel.

Cosmogenic nuclide dating (Gibbon et al. 2009) has suggested a date range for the Rietputs Formation at Riverton, up river of Canteen, of between $c .1 .9$ and $c$. 1.3 million years ago, with an average age of $c .1 .6$ mya. These gravels contain Acheulean artefacts. Presumably, the Rietputs gravels from Canteen Koppie fall within this range. However, these dates should be treated with some caution as the technique is new and requires rigorous testing. For the moment the best way of dating the site, unfortunately, remains technotypological associations.

Unit 1 which contains MSA and Fauresmith (ESAMSA transition) material will not be discussed further. Information on these is published elsewhere ((Helgren 1979; Beaumont \& Morris 1990; Beaumont 2004; de Wit 2008; Forssman et al. 2010). 
THE PREHISTORIC SOCIETY

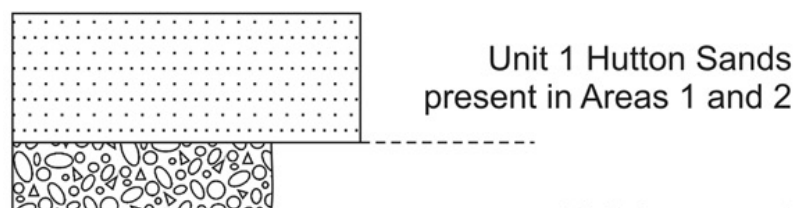

Unit 2a present in Areas 1 and 2
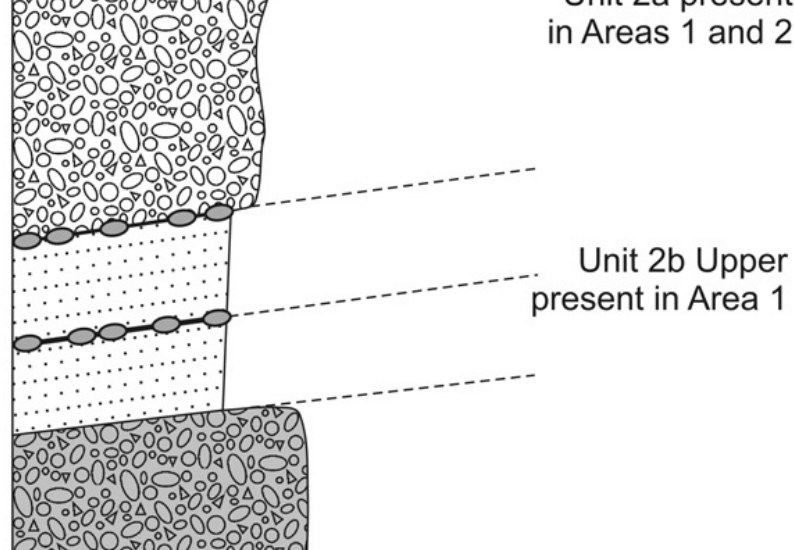

Unit $2 b$ Lower present in Area 1

Andesite bedrock

Fig. 4.

Composite schematic of the complete sedimentary sequence at Canteen Koppie. Unit 1, the Hutton Sands, are locally $0.2-5.0 \mathrm{~m}$ thick. Unit $2 \mathrm{a}$ is locally $2-5 \mathrm{~m}$ thick, and Unit $2 \mathrm{~b}$ (both sub-divisions) is up to $7 \mathrm{~m}$ thick in places

\section{THE EXCAVATIONS}

There were two excavations; Area 1 within the limits of the national monument, and Area 2 outside of it next to the boundary fence (see Fig. 3). Two trenches were opened in each. In Area 2 trench $2 \mathrm{a}$ was destroyed by renewed diamond digger activity, but trench $2 \mathrm{~b}$ was successfully excavated to bed rock. As this was originally covered by a thick deposit of Unit 1, the Hutton Sands, this trench samples the full undisturbed depth of Unit 2 a outside of the limits of the national monument. In Area 1 excavation was confined to the sides of an old diamond digger open cast pit. The diamond diggings had stripped away Unit 1 from the immediate vicinity of the two trenches excavated (trenches $1 \mathrm{a} \& 1 \mathrm{~b}$ ) and skimmed off the top of Unit 2a. However, not much of this surface was removed as undisturbed Unit 1, overlying Unit 2a, was observed directly adjacent to the Area 1 trenches. In both Area 1 and Area 2 trenches were excavated in $100 \mathrm{~mm}$ spits within the natural stratigraphy. Spits did not crosscut stratigraphic boundaries. Figure 6 shows the two trenches $(1 \mathrm{a} \& 1 \mathrm{~b}$ combined) in Area 1 . Further details of the excavation can be found in the more detailed site report on the excavations $(\mathrm{McNabb}$ \& Beaumont 2011).

In Area 1 , in the upper $300 \mathrm{~mm}$ of Unit $2 \mathrm{a}$, an assemblage of stone tools was identified whose character was markedly different from the Acheulean below it. The assemblage is consistent with descriptions of the Fauresmith (Beaumont 1999a, see Table 1), and presumably the missing few centimetres of the top of Area 1 Unit 2 a gravel contained more of this assemblage. There was a further zone of $100 \mathrm{~mm}$ depth (300-400 mm below datum) that represented a 'neutral' zone where the few artefacts present were neither unambiguously Fauresmith or Acheulean. Since this paper focuses on the Acheulean, this Fauresmith material from $0-300 \mathrm{~mm}$ will not be discussed here. Further details can be found in $\mathrm{McNabb}$ and Beaumont (2011). The remainder of this paper will concentrate on the Acheulean stone tool assemblages from the site.

\section{SIGNIFICANT ELEMENTS OF THE ACHEULEAN STONE TOOL ASSEMBLAGE AT CANTEEN KOPPIE}

A breakdown of the major elements from the Acheulean assemblages at Canteen Koppie is presented in Table 1. Further details are to be found in McNabb and Beaumont (2011). Observations will be made, where appropriate, on the similarity of the Canteen assemblages to those at the Middle Pleistocene Acheulean site of Cave of Hearths (McNabb \& Sinclair 2009), Limpopo province, South Africa (see Fig. 1). This is the only other site which has, to date, been studied using the same methodology. 


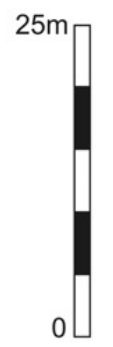

Key:

Unit 1. Hutton Sands

60000 Unit 2a. Gravels

Fi: Unit $2 b$ Upper. Sand with lines of cobbles

good Unit 2b Lower. Gravels

$\mathbb{N}$ Andesite bedrock in Pit 1

Heights refer to heights above and below site datum (see site plan)

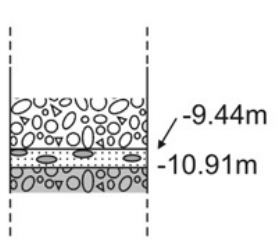

Pit 3

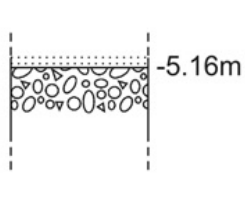

Pit 4

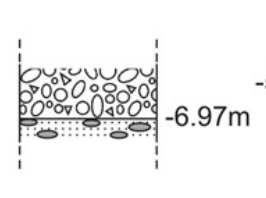

Pit 5

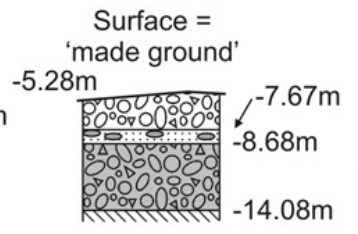

Area 1

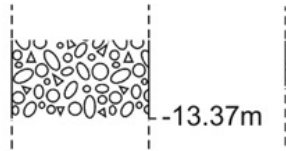

Pit 6

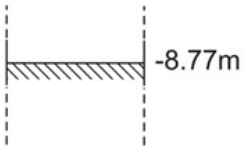

Diamond

Diggers

Fig. 5 .

Sections within and outside of the national monument boundary at Canteen Koppie. The position of the section line is shown in Fig. 3, labelled as pit transect. Fig. 4 is a composite of the sections shown here
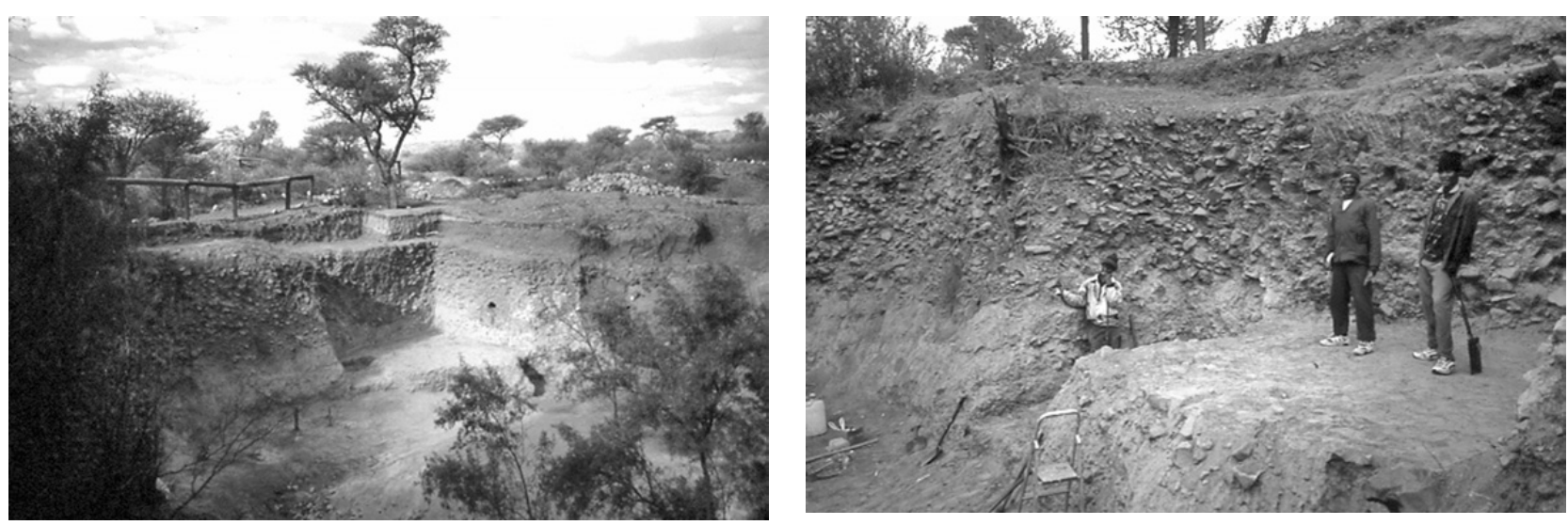

Fig. 6.

Area 1 at Canteen Koppie

a) showing the full depth of the gravels of Unit 2 a spreading out on either side of the excavation. The excavation itself is the box shaped trench dug into the side of a large diamond digger pit. The remains of the original trench, trench $1 \mathrm{a}$, can be side as a shallow oblong depression at the base of the excavation on the left hand side. The base of the excavation here is within Unit $2 \mathrm{~b}$ Upper.

b) is taken earlier in the excavation. The two figures standing together are in trench $1 \mathrm{~b}$ and stand on the unexcavated surface of Unit 2b Upper. Below them a line of 'trail' is visible. This is a distinct line of andesite clasts and artefacts, possibly a temporary land surface within the sedimentary unit. It continues behind the figure standing against the section. This figure is standing within the remains of trench $1 \mathrm{a}$ whose base is just above the base of Unit $2 \mathrm{~b}$ Upper 
TABLE 1. BREAKDOWN OF MAJOR ARTEFACT FREQUENCIES BY STRATIGRAPHIC UNIT \& BY AREA FROM CANTEEN KOPPIE. FAURESMITH DATA FROM UPPER PART OF UNIT 2A, AREA 1, INCLUDED FOR COMPLETENESS AND COMPARISON.

\begin{tabular}{|c|c|c|c|c|c|c|c|c|c|c|c|c|c|}
\hline Unit & Designation & 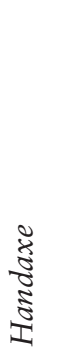 & 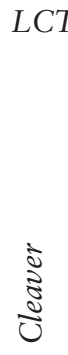 & 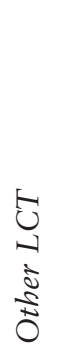 & $\begin{array}{l}\frac{\bar{d}}{2} \\
\frac{\delta}{0} \\
\frac{\delta}{2}\end{array}$ & $\begin{array}{l}\widetilde{Z} \\
\tilde{U} \\
\mathscr{2} \\
0\end{array}$ & 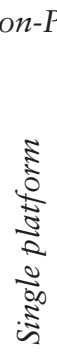 & 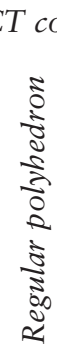 & 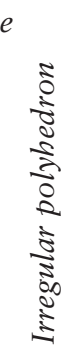 & 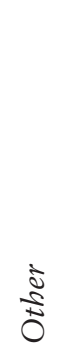 & 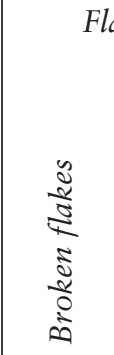 & 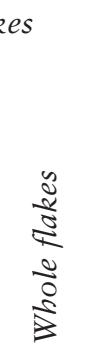 & 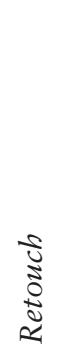 \\
\hline Area 1 Unit $2 \mathrm{a}$ & Fauresmith? $(0-30 \mathrm{~cm})$ & 2 & 0 & 0 & 6 & 2 & 2 & 3 & 28 & 4 & 632 & 235 & 9 \\
\hline Area 2 Unit $2 a$ & Acheulean & 13 & 10 & 15 & 12 & 17 & 1 & 7 & 83 & 8 & 3839 & 2657 & 30 \\
\hline Area 1 Unit $2 \mathrm{a}$ & Acheulean (below $40 \mathrm{~cm}$ ) & 10 & 11 & 8 & 11 & 21 & 1 & 14 & 118 & 9 & 2531 & 1527 & 24 \\
\hline Unit 2b Upper & Acheulean & 2 & 9 & 6 & 7 & 15 & 0 & 10 & 93 & 3 & 3152 & 1151 & 27 \\
\hline Unit $2 b$ Lower & Acheulean & 20 & 36 & 18 & 19 & 9 & 1 & 10 & 253 & 31 & 10,953 & 2982 & 89 \\
\hline
\end{tabular}

\begin{tabular}{|c|c|c|c|c|c|c|}
\hline \multirow[b]{2}{*}{ Unit } & \multirow[b]{2}{*}{ Designation } & \multicolumn{5}{|c|}{ Prepared Core Technology } \\
\hline & & 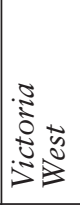 & 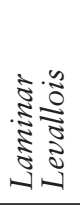 & 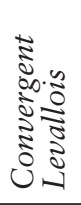 & 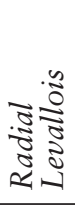 & 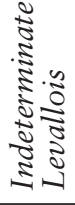 \\
\hline Area 1 Unit 2a & Fauresmith? $(0-30 \mathrm{~cm})$ & 0 & 55 & 38 & 5 & 2 \\
\hline Area 2 Unit $2 \mathrm{a}$ & Acheulean & 24 & 34 & 13 & 7 & 6 \\
\hline Area 1 Unit $2 \mathrm{a}$ & Acheulean (below $40 \mathrm{~cm}$ ) & 46 & 11 & 5 & 4 & 11 \\
\hline Unit 2b Upper & Acheulean & $3 ?$ & 4 & 1 & 3 & 3 \\
\hline Unit $2 b$ Lower & Acheulean & 0 & 0 & 0 & 0 & 0 \\
\hline
\end{tabular}

\section{Large cutting tools (LCTs)}

Despite cogent concerns with the use of the label LCT (Barkai 2009), we will use it here because it is widely understood. LCTs can be sub-divided into handaxes, defined by a convergent tip formed by extensive/invasive thinning and shaping, and cleavers identified on the presence of an unretouched cleaver bit or blade formed by one flake scar (more rarely two scars/or natural-cortex), and minimal lateral thinning and shaping (McNabb et al. 2004; McNabb 2009). Less frequent are unifaces (handaxes worked on only one face), roughouts, and large bifacial knives. These latter represent artefacts which are wedge-shaped in cross-section, with the thick end of the wedge representing all or part of one lateral margin of the LCT and thought to serve as a handle. The cutting edge opposite is bifacially worked. These three categories of LCT have been grouped together in the 'other' category in Table 1. A selection of LCTs are shown in Figure 7.

Table 1 gives the proportions of LCTs, in relation to other artefact categories found at Canteen. It makes one clear point. The received wisdom of a site overflowing with LCTs is not supported. Sample sizes vary with the sedimentary units, but LCTs occur relatively evenly distributed throughout the whole profile, from the base of Unit $2 \mathrm{~b}$ Lower to the top of Unit 2a. This means that in terms of 'cultural' designations Units $2 \mathrm{a}$ and $2 \mathrm{~b}$ are wholly Acheulean. Moving up the stratigraphic profile, Table 1 shows a distinct change in the frequency of handaxes compared with cleavers. In Unit $2 b$ Lower cleavers clearly dominate and this pattern persists into Unit $2 \mathrm{~b}$ Upper. But in the overlying Unit $2 \mathrm{a}$ the balance is 

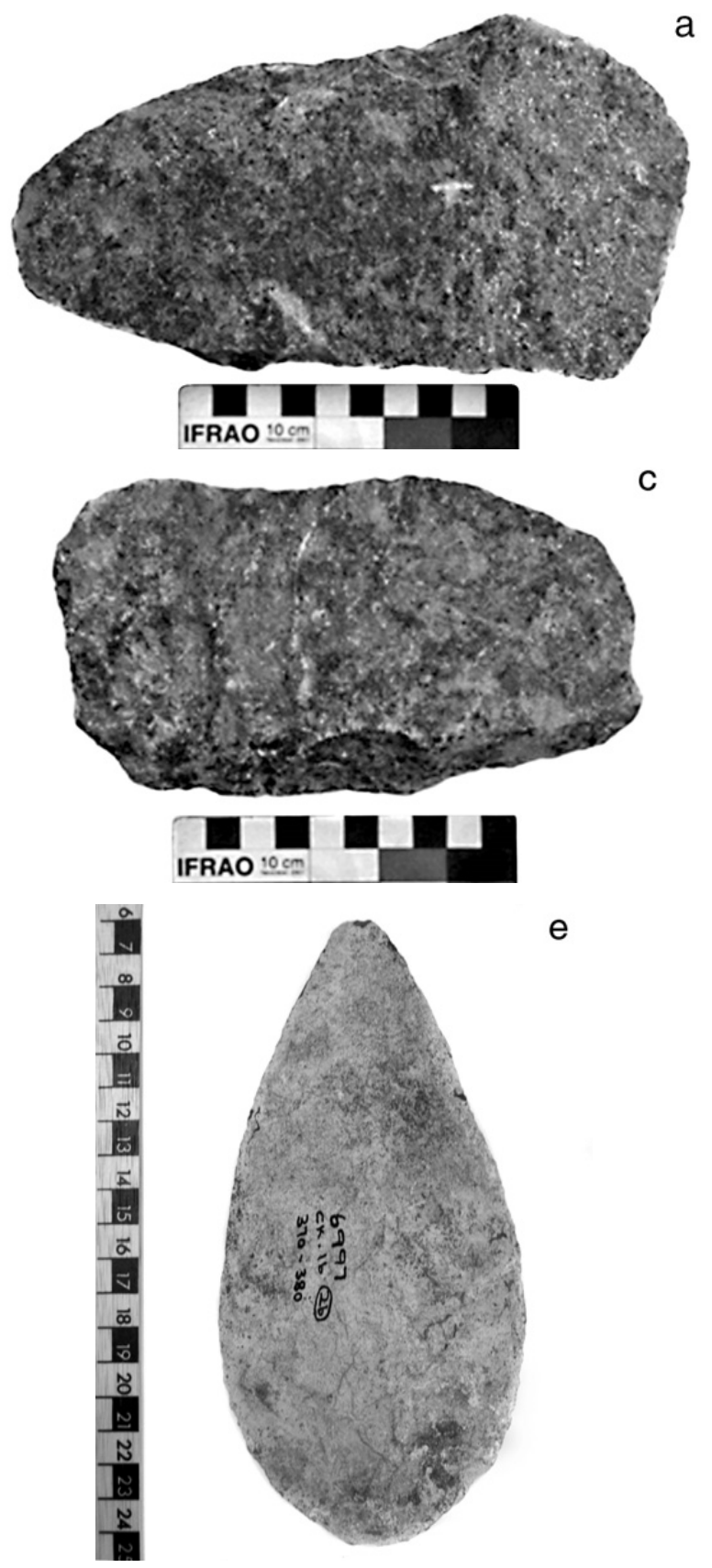

Fig. 7.

Large cutting tools (LCTs) from Canteen Koppie:a-c) three andesite cleavers from Area 1 Unit 2a. They are worn-very worn in condition; all three are made on side-struck flake blanks from pre-prepared cores (dorsal surface shown in each case); d) fresh to slightly worn andesite cleaver from the top of Unit $2 b$; e) fresh to very slightly worn handaxe from the middle of Unit $2 b$ Lower; f) side-struck flake cleaver from a pre-prepared andesite core from the basal metre of Unit $2 \mathrm{~b}$ Lower
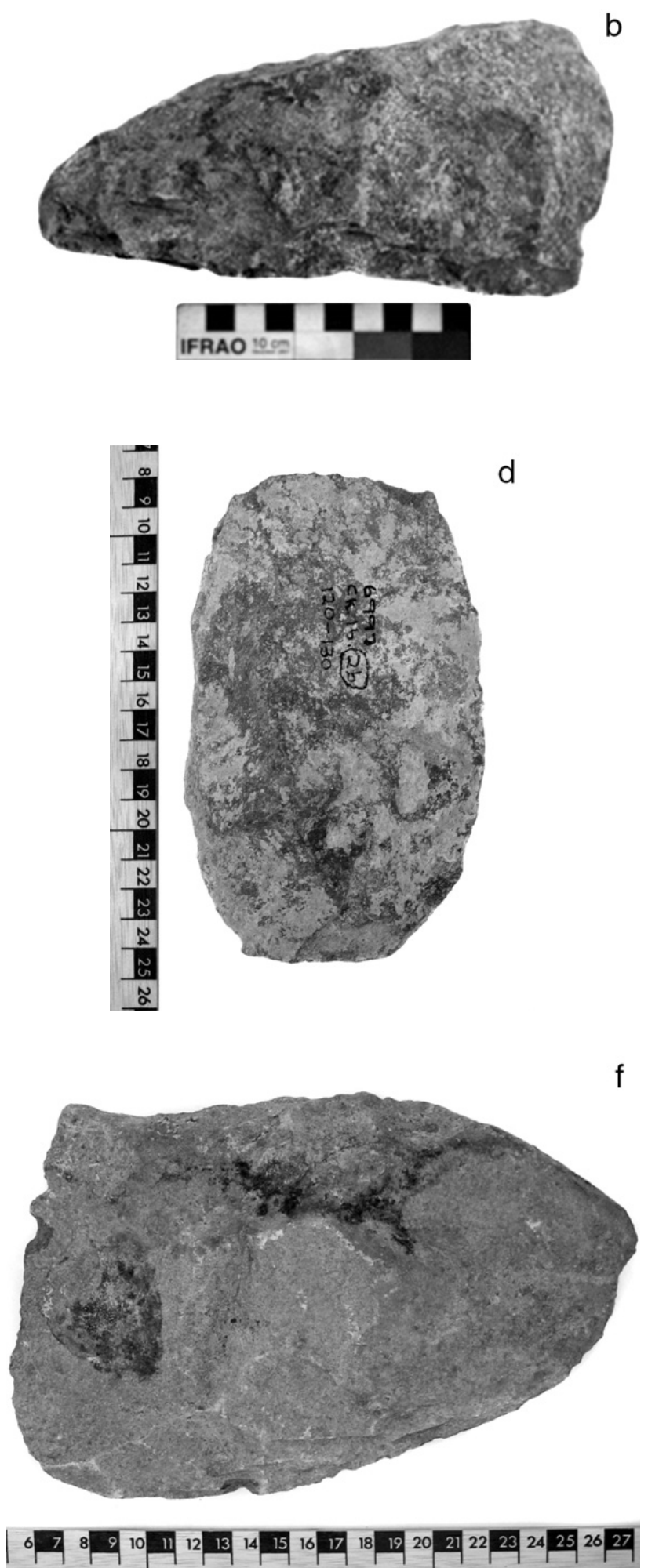
THE PREHISTORIC SOCIETY

TABLE 2. PATTERNS OF THINNING AND SHAPING ON LARGE CUTTING TOOLS FROM CANTEEN KOPPIE

\begin{tabular}{lcc}
\hline $\begin{array}{l}\text { Manufacturing patterns - pattern } \\
\text { and extent of tinning and flaking } \\
\text { on each face of an LCT* }\end{array}$ & $\begin{array}{c}\text { Andesite } \\
\text { handaxe } \\
(\mathrm{N}=19)\end{array}$ & $\begin{array}{c}\text { Andesite } \\
\text { cleaver } \\
(\mathrm{N}=59)\end{array}$ \\
\hline Complete/complete & $21.1 \%$ & 0 \\
Complete/partial marginal & $5.3 \%$ & $1.7 \%$ \\
Complete/partial & 0 & $1.7 \%$ \\
Complete/substantial & 0 & 0 \\
Complete marginal/complete marginal & $10.5 \%$ & 0 \\
Complete marginal/Partial marginal & $5.3 \%$ & $1.7 \%$ \\
Partial marginal/Partial marginal & $15.8 \%$ & $45.8 \%$ \\
Partial marginal/Partial & $5.3 \%$ & $3.4 \%$ \\
Partial marginal/substantial & $15.8 \%$ & $15.3 \%$ \\
Partial/Partial & 0 & $3.4 \%$ \\
Partial/substantial & $5.3 \%$ & $1.7 \%$ \\
Substantial/substantial & $10.5 \%$ & $6.8 \%$ \\
On one face only & $5.3 \%$ & $18.7 \%$
\end{tabular}

Combined totals for Unit $2 b$

Lower and Unit $2 b$ Upper

More extensive thinning and shaping

Less extensive thinning and shaping

Combined totals for Area 1Unit $2 a$ (below $0.40 \mathrm{~m})+$ Area 2 Unit $2 a$ More extensive thinning and shaping

Less extensive thinning and shaping

$\begin{array}{cc}\text { All } & \text { All } \\ \text { handaxes } & \text { cleavers } \\ 14 & 3 \\ (66.6 \%) & (6.7 \%) \\ 7 & 42 \\ (33.3 \%) & (93.3 \%)\end{array}$

All All

handaxes cleavers

$5 \quad 5$

$(71.4 \%) \quad(23.8 \%)$

2

$(28.6 \%)$

16

$(76.2 \%)$

*eg. Complete/partial marginal = one face completely covered by thinning and shaping/the other has thinning and shaping restricted to part of the margin)

In lower section of table more extensive thinning $\&$ shaping refers to all those categories in the upper part of the table that begin with the complete category. This also includes the substantial/substantial category. Less extensive thinning \& shaping includes all those categories which begin with partial \& includes the category on one face only. Unshaded square means no examples present

much more even. That this is a real pattern is shown by the similarity in these frequencies for Unit $2 \mathrm{a}$ in both Area 1 and Area 2. The reason for this diachronic pattern will be returned to below.

LCTs are made from andesite, hornfels, diabase, and quartzite. A particularly strong association is that between cleavers and andesite flake blanks (usually side struck). These dominate the LCT frequency counts. Handaxes on andesite flakes form the next most common association of raw material, blank, and LCT type. This is a consistent pattern throughout the vertical profile at the site. Additionally, the data suggests that when making an LCT out of a nonandesite lithology, the Canteen Koppie knappers were more likely to make a handaxe than a cleaver. Analysis of the flake scars on the dorsal faces of the cleavers demonstrates that their flake blanks were struck from pre-shaped cores which had been knapped in order to ensure the cleaver bit was a single flat flake scar (Sharon 2007; McNabb 2009). This technique is present in the lowest levels of the site and persists to the top of Unit 2a. It implies that the Acheulean 'package' arrived at Canteen Koppie fully formed. No evidence of in situ local evolution of the Acheulean is present.

Amongst the few non-andesite cleavers from the site is a single large hornfels example from Unit $2 b$ Upper. It is on a side struck flake and its single flake scar cleaver bit shows it too was detached from a preshaped core. At $128 \mathrm{~mm}$ in length this is unusually large for a hornfels artefact, and its parent core will have been larger still. Yet, this cleaver is made in precisely the same way as those in andesite, and treated to the same minimal degree of lateral edge shaping after its blank was detached. Evidently raw material difference was not a factor here. This suggests the primary rationale for its manufacture was the size of the original block. If big enough, then any lithology that could be flaked, would be, and the standardised method for producing cleaver blanks would be followed. The suggestion here is that size, linked to perceived potential of the clast/block, were the primary drivers in choosing which blocks to select for flake blank cores.

The handaxe and cleaver signal for Areas 1 and 2 is the same. The range of variation in all aspects of appearance, manufacture, and technology noted for the LCTs in one area is present in the other. Visually based tests of LCT bilateral symmetry (Machin \& Mithen 2004; McNabb et al. 2004; McNabb \& Beaumont 2011), while open to justified criticisms of subjectivity, nevertheless reflect the primary visual criteria applied by the Acheulean knappers when making these artefacts to begin with. These show a range of symmetries, from wholly symmetrical to wholly asymmetrical, however evidence of the former is very limited. No requirement to consistently 


\section{J. McNabb \& P. Beaumont. ACHEULEAN LEVELS AT EARLIER STONE AGE CANTEEN KOPPIE, NORTHERN PROVINCE, S. AFRICA}

formalise/standardise the outline shape of an LCT was present at Canteen Koppie. This is particularly evident in the cleavers. Both of these observations match those made for the Acheulean LCTs at the Cave of Hearths (McNabb 2009).

Table 2 gives the proportions of occurrence of different patterns of manufacture applied to andesite LCTs from the whole depth of the stratigraphic profile. Inspection of the primary data $(\mathrm{McNabb} \&$ Beaumont 2011) shows that the range of possible combinations is spread evenly across all of the sedimentary units in both of the excavated areas. The table shows the predominance of partial marginal working for cleavers (over $60 \%$ of the sample if the two most frequent partial marginal combinations are combined). This explains why levels of asymmetry are higher in cleavers. On the other hand, handaxes show greater attention to thinning and shaping and have more combinations demonstrating invasive shaping. The reason for this is that when making a handaxe, the knappers paid greater attention to the upper half of the LCT in order to fashion the converging tip. As a consequence of this handaxes naturally show greater working in their upper halves than do cleavers, and a greater likelihood for symmetry to be manifested in the tip region of the axe. Whether higher degrees of symmetry in the tips of handaxes were intended by the knapper, or were an accidental consequence of greater working on the tip (personal opinion of JM) remains to be demonstrated. Again, this is the same pattern as seen in the Cave of Hearths handaxe assemblage (ibid.). There is a strong synergy between the patterns of manufacture and final appearance for LCTs at both sites.

Of significance is the question of whether the LCTs at the top of the sedimentary column show any advance in technique or appearance over those lower down. The answer is no. The range of variation in visual appearance and manufacture is similar throughout. This is addressed through the percentage totals in the lower half of Table 2. In both the upper and lower halves of the stratigraphic sequence, cleavers are more frequently worked by any pattern of thinning and shaping that involves minimal working. Almost always this involves lateral trimming of the edges and removal of the butt of the andesite flake blank.

Overall, the LCT component of the lithic assemblage at Canteen Koppie shows a consistent picture throughout the depth of deposits, and from both locations at the site. It is directly comparable to other Acheulean assemblages along the Vaal (JM pers. obs.), and to other Acheulean sites in South Africa and elsewhere (Sharon 2007; 2008). There is no evidence for internal evolution or increasing technological sophistication in the LCTs at the site. There is a strong conceptual tethering between LCTs, raw material size, flake blank production, and an un-standardised finish/appearance. Once more, this reflects the same data from Cave of Hearths. Here the tether was between flattish blanks (primarily quartzite flakes and slabs) and a dominance of cleavers. As in Canteen Koppie, the driver for LCT flake blank production was size (McNabb 2009). At Cave of Hearths, flakes and blanks too small for LCTs became discoidal cores. The consistently different degrees of finish/manufacturing pattern applied to cleavers $v s$ handaxes, implies these two tool forms were conceived of as very different entities by the Acheulean knappers.

\section{Ordinary flake cores not worked by prepared core technology - non-PCT cores}

These represent flake cores which display no evidence of preparation of the surface of the core, and no hierarchical relationship between any of core's flaking faces (Boëda 1995). Choppers, discoids, and single platform cores (more properly single surface cores) follow conventional usage of these terms (Leakey 1971; Kuman 1996). Regular polyhedrons are here defined as spherical/near-spherical in shape and their surface is mostly flake scars. Irregular polyhedrons are cores whose shape does not fit comfortably into any of the other shape categories (McNabb 2009; McNabb \& Beaumont 2011). Table 1 provides the summary data for the frequency of cores in the individual sedimentary units at Canteen Koppie. Table 3 compares core type with raw material, blank type, and blank/clast size. The totals from each of the sedimentary units have been combined to increase sample size. This is justified because all of these core forms were the same, and consistently knapped using the same range of techniques, applied in the same way throughout the stratigraphic sequence.

There is a clear preference for andesite over other lithologies (see Table 3), and a dominance of fluvial clasts as blank types (ranging from rounded and angular, to sub-rounded and sub-angular shapes); clasts represent $83 \%$ of the cores in this lithology. The non-quartzite raw materials are hornfels, chalcedony, quartzite, and a variety of fine grained chert-like 


\section{THE PREHISTORIC SOCIETY}

lithologies in a range of colours; white, green, red, red with grey streaks, and black. This reflects the natural occurrence of these different rock types within the Vaal gravels (de Wit 2008). The natural predominance of andesite not-withstanding, there is no exclusive relationship between any one particular rock type and a specific core type; almost all of the different shapes of core appear on any lithology/clast large enough to be flaked. In this sense, raw material did not have any limiting influence on the flaking of cores, a situation paralleled in the LCTs. These different types of cores are those most commonly found in African ESA assemblages, and they are present from the bottom of Unit $2 \mathrm{~b}$ Lower all the way up to the top of the sequence. There are no diachronic trends. The pattern of flaking techniques applied to these non-PCT cores is no different from those seen at other African ESA sites.

Andesite and rounded/sub-rounded clasts were the most common raw material to blank combination because this was what occurred most commonly along the river bank. Within this combination, the overwhelming dominance of irregular polyhedrons is interesting. It reflects the primary reason the hominins came to Canteen Koppie, at least in terms of the lithic assemblages. The size of the raw material available provided them with a source for making the largest possible flake blanks for LCTs.

In the lower section of Table 3 the data for size categories (Thornes 1979) presents information about cores made on gravel clasts whose size on abandonment was boulder-sized $(>256 \mathrm{~mm}$ in maximum length), cobble-sized $(64-256 \mathrm{~mm})$, or pebble-sized $(<64 \mathrm{~mm})$. There is a clear pattern in the Canteen Koppie data. Using the tripartite size division as a proxy for original clast size, boulder and cobblesized cores tend to be made out of andesite more often, and were likely to have been targeted for largeflake production as judged on the size of the remnant flake scars on the cores. On the other hand in the nonandesite lithologies, smaller cobbles and pebbles were more frequently selected. Is this considered deliberate? Only in part. We interpret this to reflect the naturally occurring size ranges of these lithologies in the river's bed-load. Andesite was knapped for large flake blanks because it naturally occurred in appropriately sized clasts that facilitated this requirement. This is made clear in the box and whisker plots in Figure 8, where the overlap between the maximum lengths of andesite LCTs, and the flake scars on boulder-sized and cobble-sized cores is evident. The size range of the non-andesite lithologies was naturally smaller, so they were not targeted for the production of flake blanks for LCTs. Why then were they knapped? Presumably for smaller flakes, or for their use as tools (see below).

This still leaves the question of why, at Canteen Koppie, there is a preponderance of irregular polyhedrons? When large boulders and cobbles are flaked they automatically produce this core morphology after a few detachments. The core working data demonstrates that boulder cores were less intensively worked than the cobble and pebblesized cores. Our suggestion for this is that knappers deliberately targeted the largest boulders and cobbles in order to take off the biggest flakes and these were intended as LCT blanks. After a few such detachments, or when the core began to make somewhat smaller flakes, it was abandoned. Although the core was not exhausted, it was not providing flakes of the right preconceived size for LCT blanks. Therefore the knappers chose a new core to work. There was no shortage of boulder and larger cobblesized andesite clasts in the area. The irregular polyhedron form is a natural result of limited flaking on big clasts. That the boulder cores were worked less intensively than other cores is supported by the following data; the mean number of scars on andesite boulder-sized cores is $6.78(\mathrm{~N}=111, \mathrm{SD}=3.51)$, and on cobble-sized cores $8.03(\mathrm{~N}=474, \mathrm{SD}=4.22)$. A schematic reconstruction of one of the ways of reducing an andesite boulder core in order to produce an LCT blank is shown in Figure 9.

However one aspect of the non-PCT cores at Canteen Koppie did come as a surprise. This was the presence of the smaller cores noted above. These are cores in the pebble-sized group, some as small as 27 $\mathrm{mm}$ in maximum dimension. They were present in all the layers at the site and were excavated from the sediments with the other artefacts. There is no question of them being intrusive. There were 98 in all, of which only six were andesite. If found on the surface they would, on the basis of size, have been interpreted as later MSA or more likely Later Stone Age (LSA). It is difficult to imagine how flakes from these were used, unless they formed part of small composite tools, and to date there is little evidence for composite technology reported from any African Lower or Middle Pleistocene sites. As tools in themselves most of these cores would be too small to use (just over $74 \%$ are $=<55 \mathrm{~mm}$ in maximum length), and few presented convincing working edges. 
J. McNabb \& P. Beaumont. ACHEUlEAN LEVELS AT EARLIER STONE AGE CANTEEN KOPPIE, NORTHERN PROVINCE, S. AFRICA

TABLE 3. DETAILS OF RAW MATERIAL TYPE, BLANK MORPHOLOGY, AND CORE TYPE IN THE NON-PREPARED CORE TECHNOGROUP AT CANTEEN KOPPIE

\begin{tabular}{|c|c|c|c|c|c|c|c|c|c|c|}
\hline \multirow[t]{2}{*}{ Raw Material } & \multirow[t]{2}{*}{ Blank } & \multicolumn{9}{|c|}{ Core types } \\
\hline & & 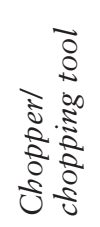 & 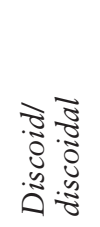 & 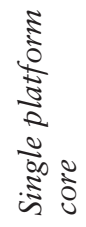 & 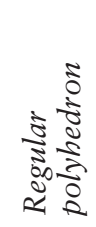 & 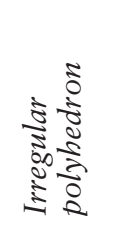 & 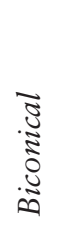 & 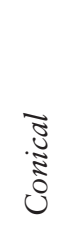 & 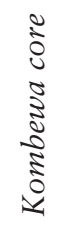 & 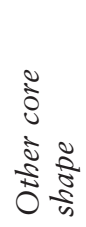 \\
\hline Andesite & Flake & 0.2 & 0.7 & 0.2 & & 2.2 & & & 1.0 & 0.7 \\
\hline \multirow[t]{3}{*}{$\mathrm{N}=595$} & Clast & 3.5 & 1.5 & & 3.0 & 73.5 & 0.3 & 0.5 & & 0.7 \\
\hline & Slab & 0.2 & 0.2 & & & 2.0 & & & & 1.0 \\
\hline & Indet. & & 3.7 & & 2.4 & 1.3 & 0.5 & & & 0.8 \\
\hline Non-andesite & Flake & & & & & & & & & \\
\hline \multirow[t]{3}{*}{$\mathrm{N}=152$} & Clast & 16.5 & 5.3 & 0.7 & 2.0 & 39.5 & & & & 3.3 \\
\hline & Slab & & 1.3 & 0.7 & & 2.0 & & & & \\
\hline & Indet. & 0.7 & 10.5 & & 4.0 & 9.2 & 0.7 & 0.7 & & 3.3 \\
\hline Totals & & 49 & 62 & 3 & 41 & 547 & 6 & 4 & 6 & 29 \\
\hline \multirow[t]{2}{*}{ Raw material } & \multirow[t]{2}{*}{$\begin{array}{l}\text { Equivalent co } \\
\text { size for clas } \\
\text { blanks only }\end{array}$} & & & & & ore types & & & & \\
\hline & & 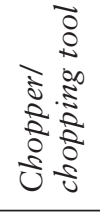 & 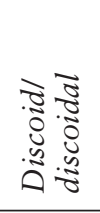 & 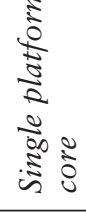 & 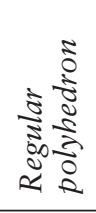 & 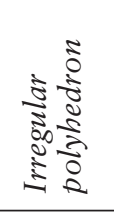 & 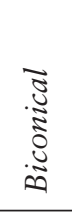 & 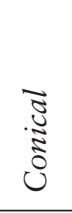 & 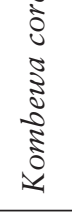 & 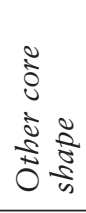 \\
\hline Andesite & Boulder & & & & 0.2 & 21.8 & & & & \\
\hline $\mathrm{N}=491$ & Cobble & 4.1 & 1.8 & & 3.1 & 66.4 & 0.4 & 0.6 & & 0.8 \\
\hline & Pebble & 0.2 & & & 0.4 & 0.2 & & & & \\
\hline Non- & Boulder & & & & & 1.0 & & & & \\
\hline Andesite & Cobble & 16.8 & 3.0 & & 1.0 & 18.8 & & & & 2.0 \\
\hline $\mathrm{N}=101$ & Pebble & 6.9 & 5.0 & 1.0 & 2.0 & 39.6 & & & & 3.0 \\
\hline
\end{tabular}

Percentages refer to raw material row totals. Boulder $=$ cores with a maximum length of $>256$ mm. Cobble $=$ cores with a maximum length between $64 \mathrm{~mm}$ and $256 \mathrm{~mm}$. Pebble $=$ cores $<=64 \mathrm{~mm}$.

Nevertheless these small cores, often cuboid in shape, represent an infrequent yet persistent part of the Acheulean non-PCT core working repertoire.

At the Cave of Hearths a different core working strategy was present, but as with that at Canteen, it was an adaptation of requirement to local circumstances. The most common rock type for tool manufacture was the local fine grained quartzite. At the cave, the data suggests ( $\mathrm{McNabb} 2009)$ that large flake blanks and slabs of flattish rock were brought into the cave already partially worked into handaxes or cleavers. Although there was a stream bed in front of the cave, the frequency of fluvial clasts used as blanks for LCT production was limited. Most of the natural blanks used for LCTs were slabs of scree from collapsing cliffs at the head of the stream a few $\mathrm{km}$ distant. Otherwise, the major blank type was a flake knapped from pre-prepared cores. Flattish discoidal cores predominate over all other core forms. This reflects the psychology behind the choice of appropriate blanks for LCTs at the site, those too small for transformation into handaxes or cleavers became 


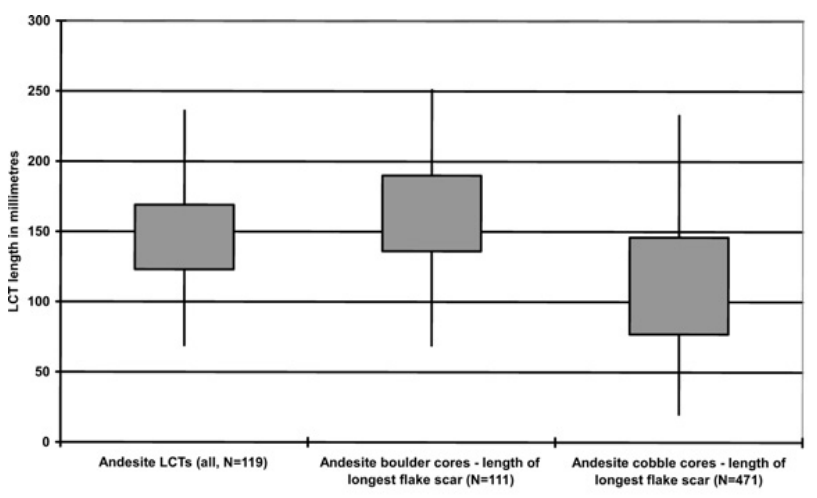

Fig. 8.

Boxplots comparing the maximum length of LCTs with the lengths of the longest scars on those cores of sufficient size from which LCT blanks could have been detached

discoids. It has been suggested (ibid.) that some of the discoids may have been made to serve as impromptu LCTs. As with Canteen Koppie, the flakes from the discoids would have been small and difficult to use.

\section{Unretouched flakes and small retiruched tools/flake tools}

Basic data are presented in Table 1, however the unretouched flake and debitage component of the Acheulean assemblages at Canteen Koppie will not be discussed here. Full details are presented elsewhere (McNabb \& Beaumont 2011).

One implication of the discussion of flake cores above, is that a two-tier perception of cores and their flakes existed in the minds of the Acheulean knappers at Canteen Koppie. Firstly, that andesite boulder cores and larger cobbles were worked for LCT blanks. Secondly, smaller cobble-sized cores, and pebble-sized cores, especially in the non-andesite lithologies, were knapped for other reasons. Analysis of the flake tool component puts pay to one possible explanation for this pattern very quickly. The knapping of the smaller cores at Canteen Koppie was not focused on blank production for retouched flake tools. Table 4 presents the data for all the retouched pieces from Unit $2 b$ Lower, 2b Upper, and Unit 2a (both areas). Clearly flake tools were not an important part of the knapping activities at the site throughout the whole of the time it was visited by hominins. Retouching was noted to have occurred on broken and unbroken

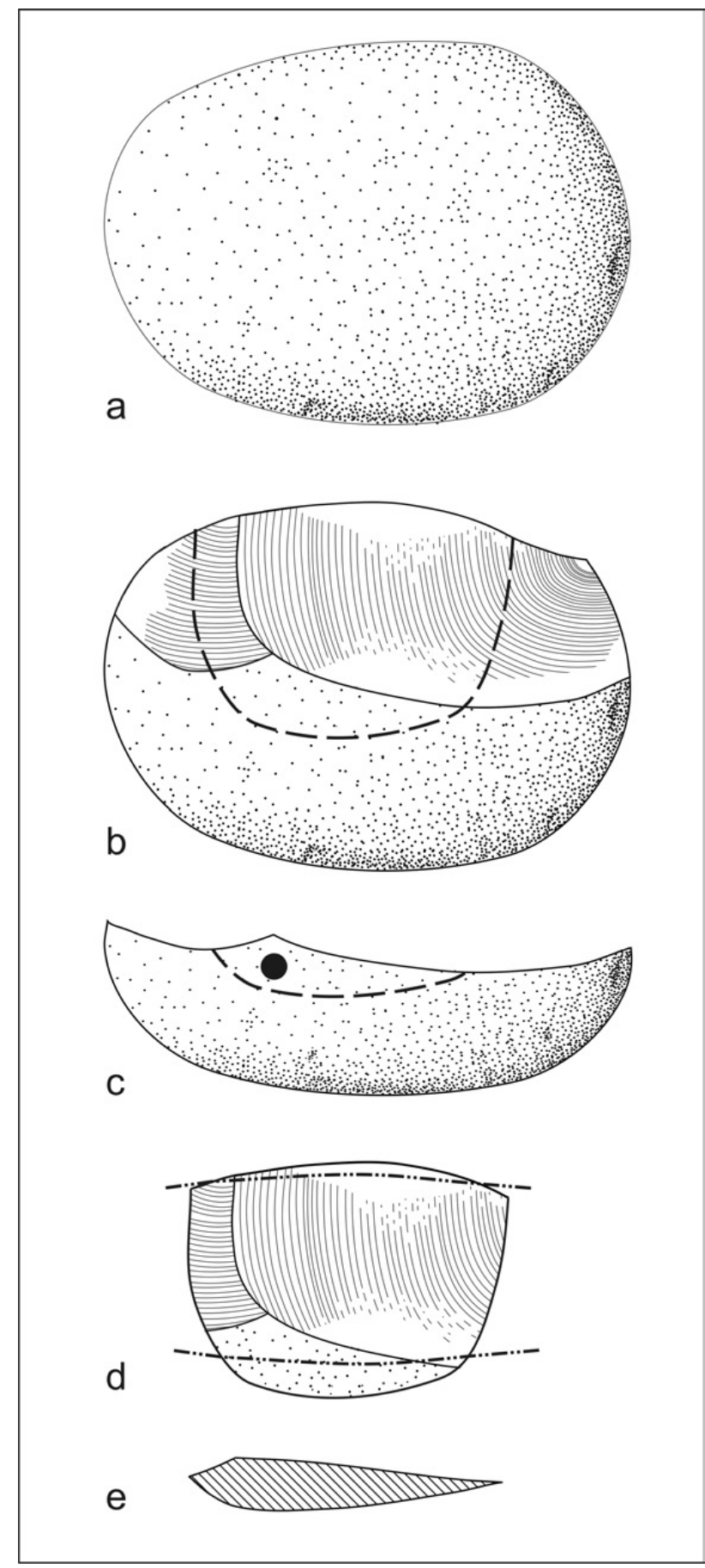

Fig. 9.

Schematic reconstruction of one of the ways in which andesite boulders (a) could have been flaked (b \& c) in order to set up the removal of a cleaver blank (d) which is subsequently trimmed marginally (dotted lines on d). Its cross-sectional shape is shown in (e) 
J. McNabb \& P. Beaumont. ACHEUlEAN LEVElS AT EARLIER STONE AGE CANTEEN KOPPIE, NORTHERN PROVINCE, S. AFRICA

flakes. The retouched pieces $(\mathrm{N}=170)$ amount to $0.03 \%$ of all the broken and unbroken flakes $>=41 \mathrm{~mm}$ in length $(\mathrm{N}=6458)$.

If we assume that the majority of flake tools (scrapers, knives, denticulates, etc) were originally used in processing activities, then these data imply that such activities were not part of the suite of hominin behaviours practised at the site (or perhaps at least not at this part of the river bank). Unfortunately, it is not possible to be certain whether or not the smaller cores were used as tools in place of retouched flakes. The depositional environment precludes any remnants of use-wear surviving on tools' edges.

However, focusing on the retouched tools that are present, it is clear that there is an emphasis on sharp unretouched edges over the retouched ones. Flaked flakes and their spalls, both of which share very sharp edges (Ashton et al. 1991), are the most common small tool form, which when combined with the totals for flaked flakes on multiple tools $(\mathrm{N}=86)$, represents just over $58 \%$ of the small/retouched tool component. Perhaps this emphasis on sharp edges is a clue as to why the retouched tool count is so low. Whatever tasks required the use of a smaller tool, they were jobs best performed by sharp edges rather than retouched ones. The super-abundance of sharp-edged flakes just lying around on the surface of the river bank may have been sufficient for almost every requirement, occasionally supplemented by a flaked flake or its spall. Tasks requiring a retouched edge may have been performed away from the river bank.

No convincing retouched points occur in the lower units (2b), those that were present were atypical and represented a single line of retouch enhancing a fortuitously pointed natural shape. It would be unwise to make too much of these. Their presence in Unit 2a, with Levallois, is less surprising.

This pattern of few flake tools, and an emphasis on the sharp-edged morphologies, was also noted at Cave of Hearths. It is interesting that this should be the case. The overall interpretation of Canteen Koppie is that it was a factory site primarily aimed at the production of large flakes for LCTs. A lack of processing activities requiring a large flake tool component is understandable. The Cave of Hearths, however, is more likely to have been a locus of habitation, albeit for a small group of hominins possibly visiting infrequently over many hundreds or thousands of years. The lack of a larger complement of processing tools in these circumstances is more unusual.
TABLE 4. FREQUENCIES OF RETOUCHED TOOLS/FLAKE TOOLS FROM ALL ACHEULEAN LAYERS AT CANTEEN KOPPIE

\begin{tabular}{lcc}
\hline Small retouched tool type & Andesite & Non-andesite \\
\hline Side scraper & 8 & 1 \\
Transverse scraper & 10 & 1 \\
Convergent scraper & 2 & 1 \\
Double scraper & 1 & 2 \\
Perimetal scraper & 1 & 0 \\
Flaked flake incl. (spalls) & $68(22)$ & 9 \\
Denticulate & 12 & 1 \\
Retouched Point & 3 & 4 \\
Knife & 5 & 0 \\
Non-diagnostic retouch & 10 & 0 \\
Multiple-flaked & 4 & 0 \\
flake+scraper & & \\
Multiple-flaked & 4 & 0 \\
flake+denticulate & & 0 \\
Multiple-flaked & 1 & \\
flake+non-diagnostic & & \\
\hline
\end{tabular}

\section{Prepared core technology (PCT)}

This comprises the three variants of Levallois (laminar or blade/parallel, point/convergent, and flake/radial), the Victoria West technology, and two types of core technology that are conceptually akin to PCT - these are the Kombewa, and simple prepared cores (see below). The relationship of these varieties of PCT to each other, and whether the label Levallois should be applied as a blanket term for all of them, is discussed by Sharon (Sharon 2009). The use of the Levallois concept as understood here follows Böeda (1995).

\section{VICTORIA WEST}

This is restricted to Unit $2 \mathrm{a}$, and is present in both Area 1 and Area 2. Broader discussions of this technology and its history of study in South Africa are to be found elsewhere (Van Riet Lowe 1945; Kuman 2001; Sharon 2007; Lycett 2009).

The most common of the three Victoria West core forms seen at Canteen Koppie (McNabb 2001) is the side struck variant (Table 5), which at Canteen often has an asymmetric almond-shape outline (holding the core with the preferential flaking face toward you, proximal of the main/preferential scar uppermost). The tapering end is on the right hand side, and the Victoria West flake will have been detached from a point closer to the taper than the centre. A classic example is shown in Figure 2, above. The second morphology, the end-struck form, has an elongated preferential flake scar and the core's shape is longer than it is wider in this orientation. Finally, generalised Victoria West cores represent cores with a large central removal, detached from the middle of the striking platform, cutting through a series 
THE PREHISTORIC SOCIETY

TABLE 5. DETAILS OF ALL TYPES OF PCT AT CANTEEN KOPPIE

\begin{tabular}{|c|c|c|c|c|c|}
\hline \multirow{2}{*}{$\begin{array}{l}\text { PCT category } \\
\text { From Unit } 2 a \\
\text { Areas } 1+2\end{array}$} & \multirow[t]{2}{*}{ PCT type } & \multicolumn{2}{|c|}{ Unit $2 a$ (Areas 1+2) } & \multicolumn{2}{|c|}{ Unit $2 b$ Upper } \\
\hline & & Andesite & Non-andesite & Andesite & Non-andesite \\
\hline \multirow[t]{10}{*}{ PCT - cores } & VW side struck & 38 & 0 & 0 & 0 \\
\hline & VW end struck & 14 & 0 & 0 & 0 \\
\hline & VW general & 17 & 1 & $3 *$ & 0 \\
\hline & Blade & 0 & 0 & 0 & 0 \\
\hline & Simple prepared & 1 & 0 & 0 & 0 \\
\hline & Flake-blade & 2 & 0 & 0 & 0 \\
\hline & Convergent & 1 & 0 & 0 & 0 \\
\hline & Radial & 1 & 1 & 0 & 0 \\
\hline & Roughout & 5 & 0 & 0 & 0 \\
\hline & Indeterminate & 2 & 1 & 2 & 1 \\
\hline \multirow{8}{*}{$\begin{array}{l}\text { PCT - } \\
\text { preferentially } \\
\text { detached }\end{array}$} & VW s.s. flake & 0 & 0 & 0 & 0 \\
\hline & VW e.s. flake & 0 & 0 & 0 & 0 \\
\hline & VW gen. flake & 0 & 0 & 0 & 0 \\
\hline & Blade & 27 & 2 & 3 & 1 \\
\hline & Flake-blade & 14 & 0 & 0 & 0 \\
\hline & Convergent & 13 & 4 & 1 & 0 \\
\hline & Radial & 8 & 1 & 3 & 0 \\
\hline & Indeterminate & 6 & 3 & 0 & 0 \\
\hline
\end{tabular}

Pieces marked with * refer to three cores considered to fortuitously resemble Victoria West. Pieces marked s.s. are side struck

of (usually radially removed) flake scars. There is little to no evidence of careful shaping of the core's planform or of its preferential flaking face. It is by no means certain that this third variant is Victoria West sensu stricto. Nevertheless, the scar patterning is visually very distinctive, and they have tentatively been included within this PCT category.

The data for Victoria West at Canteen Koppie is presented in Table 5, along with other examples of PCT technology. A consistent pattern emerges from the data; classic Victoria West technology (side and end struck) is almost exclusively in andesite, and is represented only by the cores; no convincing examples of Victoria West flakes were present, a feature noted by Goodwin in the early 1930s (1934). The one banded quartzite example of generalised Victoria West in the table is probably better interpreted as a simple prepared core (see below - JM pers. obs.).

One other point of significance is brought out in the data. While there are no convincing examples of Victoria West technology in Unit $2 b$, there is Levallois in Unit $2 b$ Upper, albeit infrequent, and it is not very typical. However in Unit $2 \mathrm{a}$, the two technologies are unambiguously present together. Three examples of side struck Victoria West cores from Unit $2 \mathrm{a}$ are shown in Figure 10.

Could the preferential flakes from the Victoria West cores provide blanks for the LCTs? The data on this question is clear and unambiguous - yes. This is illustrated in Figure 11, where the overlap between the inter-quartile ranges for overall length of LCTs and Victoria West preferential flakes (as judged by their scars) is evident. It should be recalled that the flakes from these scars would be somewhat larger as, often, the edge of the core was removed along with the flake (Sharon and Beaumont 2006).

Is it possible to tell what kind of LCTs these flakes were used to make? On the basis of the data no, but it is possible to speculate. Sharon and Beaumont (2006) have argued that the flakes are made as blanks for cleavers. In the opinion of one of us (JM) they were not. It has already been shown that cleavers at Canteen are made on side-struck flakes, and generally show a limited amount of thinning and shaping which is usually restricted to intermittent marginal working. Their cleaver bits are single flake scars lacking secondary working (apart from at the margins). The features one would expect to see on flake blanks made from Victoria West side/end struck cores would be a wide convex shaped cleaver bit. It would show signs of at least two or more flake scars and arêtes (sometimes in a radial pattern) from the shaping of the core's broad/convex end. On side struck flakes the end opposite the convexity would very often be markedly convergent, reflecting the tapering 'point' of the core.

This pattern is not present on the Canteen Koppie cleavers. Manufacturing methods like that in Figure 9 best reflect the cleavers at the site. So at Canteen Koppie at least, the Victoria West technique is not aimed at producing cleaver blanks. However, Sharon's interpretations may apply at other sites

In that case what were the Victoria West flakes at Canteen Koppie used for? Handaxes are the only logical alternative (contra McNabb 2001). The basic teardrop 


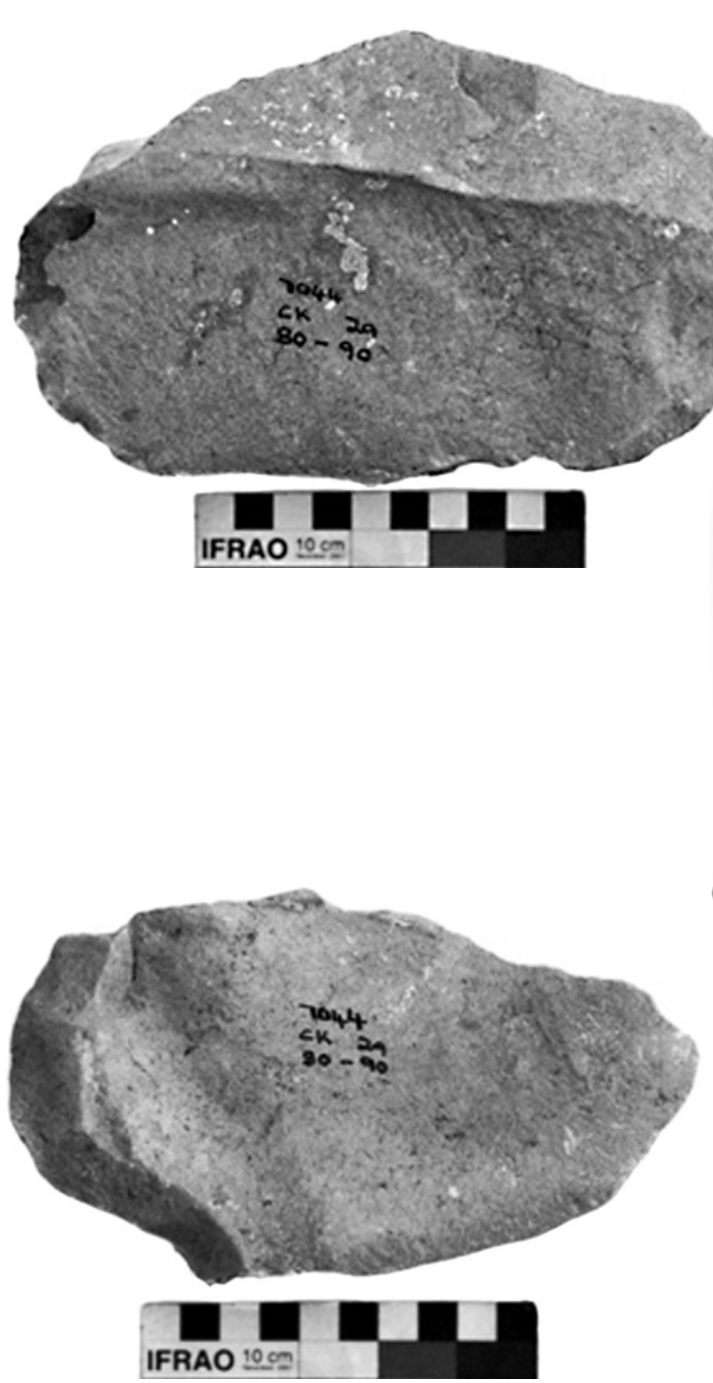

a

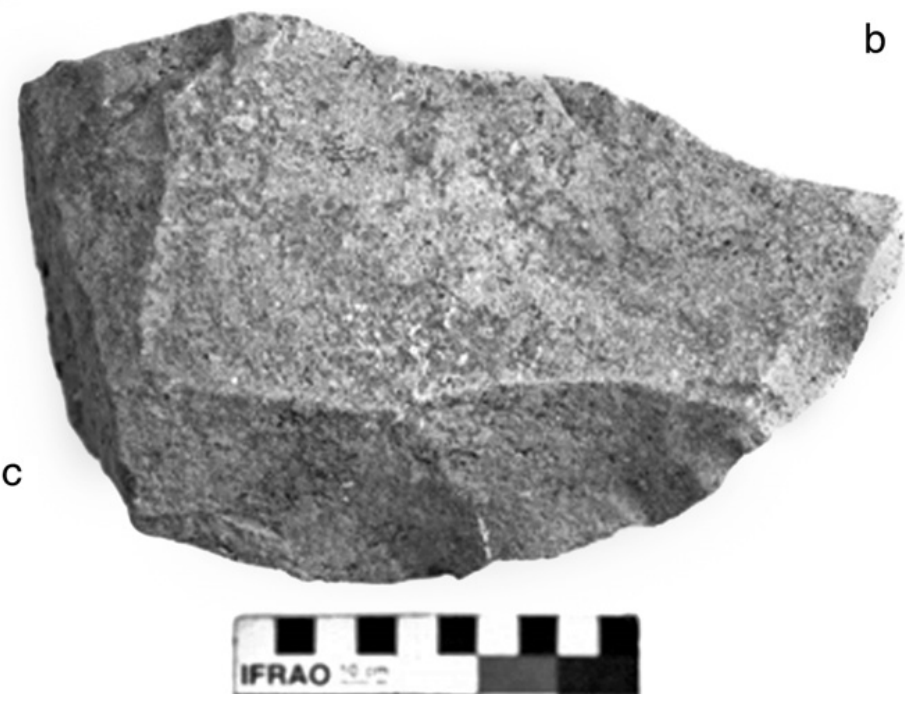

Fig. 10 .

Three andesite side struck Victoria West cores from Unit 2a. All are from Area 2 and from the same spit, situated approximately a third of the way down from the top of the gravel. The three cores show that although the approach to flaking a Victoria West core was systematic, the resulting preferential flakes could be very variable shape is already present, and its asymmetrical planform (almond shape) could be quickly altered by thinning and shaping. In order to turn the taper into a proper point there would have to be substantial working of the tip - a feature already noted on handaxes from Canteen (see above). The degree of thinning and shaping would be greater, covering more surface area than on a cleaver, also noted.

Given that the Victoria West is confined to Unit 2a, does this denote a change in LCT behaviour between the two sedimentary units; or in other words does the new technology accompany a new emphasis on handaxes? There is a suggestion in the data that this is the case. Table 1 shows that there is a drop in the frequency of cleavers, relative to handaxes in Unit $2 \mathrm{a}$ when compared to Unit $2 \mathrm{~b}$. It is possible to tentatively link the appearance of Victoria West at Canteen Koppie with a rise in the importance of handaxes at the expense of cleavers - a shift in hominin tool behaviour. Whether or not this should be considered as a distinctive break in cultural terms is less certain. It should be emphasised that the Unit $2 \mathrm{~b}$ to Unit $2 \mathrm{a}$ Acheulean signal is otherwise unaffected.

\section{LEVALLOIS}

A small number of isolated pieces from Unit $2 \mathrm{~b}$ Lower fortuitously resemble Levallois detachments. However, they are not considered genuine examples of PCT. As Table 1 and Table 5 show, there are more in the pinkish sands of Unit $2 b$ Upper. None of these are particularly classic examples either. A convergent detached piece from near the base of Unit $2 \mathrm{~b}$ Upper is the most convincing, only unusual for its size $(125 \mathrm{~mm}$ long). Presuming these tentative identifications of Levallois are correct, this technology was very infrequently practiced in Unit $2 \mathrm{~b}$ Upper times. 
THE PREHISTORIC SOCIETY

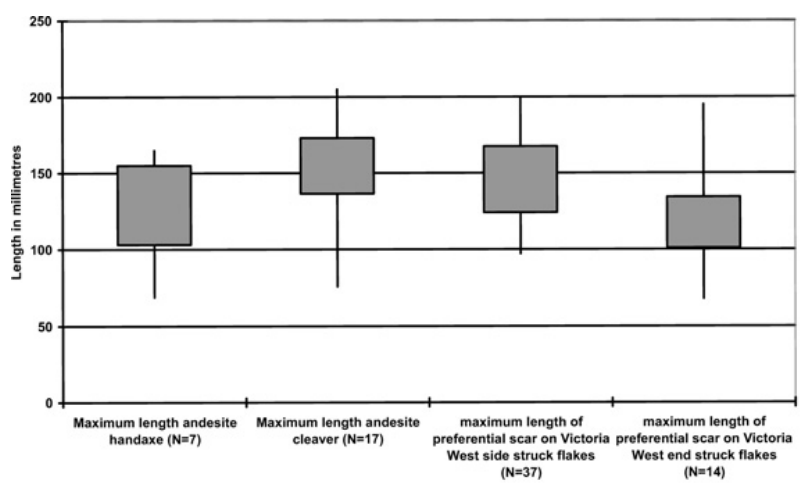

Fig. 11.

Boxplots comparing the maximum lengths of handaxes and cleavers, with the maximum length of preferential flake scars on side and end struck Victoria West cores from Unit $2 \mathrm{a}$ at Canteen Koppie

The various Levallois variants are thinly but evenly scattered throughout the depth of Unit $2 a$, and this pattern holds good for Areas 1 and 2. It is present at the top of the unit in both areas, and is present at the base in Area 1, along with Victoria West, but is $0.50 \mathrm{~m}$ shy of the base in Area 2, which has Victoria West slightly below this. In both areas therefore, the two different PCT technologies are evidently contemporary, at least in terms of the formation of the sedimentary unit. It should also be noted there are fresh and worn examples of Levallois distributed throughout the gravel (as there are LCTs).

The character of the Levallois from Unit $2 \mathrm{a}$ is strongly laminar and convergent, dominated in these samples by detached pieces. Blade cores are absent, but there are two flake-blade cores, one from each area, one a recurrent unipolar core, the other recurrent bipolar. The low radial count is intriguing, and it would be interesting to know whether laminar/convergent techniques inversely co-vary with the radial technique elsewhere.

\section{KOMBEWA}

This technology involves detaching a large flake, which is here called a Kombewa flake spall, from the ventral face of a larger flake. The Kombewa flake spalls are used as the blanks for handaxes and cleavers, particularly the latter. These flake spalls are janus flakes, having two ventral faces, only one of which will be the spall's true ventral. Kombewa flake-core frequencies (the parent flake from which the flake spall was detached) were included in Table 1 under the label 'other cores' but they represent a curious problem in terms of classification. They are included in Table 3 which summarises the data for non-PCT cores, but are discussed here in the PCT section of this paper. They do not contribute to the totals in Table 5. Why is this? They represent an enigmatic technology which could fit in either PCT or nonPCT pigeon-holes, and as such these artefacts serve as a warning about applying too rigid a classification to continuums of practice that were almost certainly never conceived of in such a way by the original knappers. Kombewa flake-cores lack any form of surface preparation of the flake-cores' ventral face. So technically they cannot be prepared cores. Yet, conceptually, they are more akin to prepared core technology. The unshaped ventral face of the Kombewa flake-core is a hierarchically conceived preferential flaking face. On the one hand the natural convex surface of a large flake's ventral face requires no preparation in order to detach a suitable flake blank. But on the other, a single preferential flake is detached from a surface whose importance is evidently greater than the opposite dorsal face.

It is very clear from the tables that Kombewa technology is infrequently practised. The cores occur in layers were cleaver flake blanks were already being detached from preshaped cores, and boulder cores are more frequent anyway. They are probably a reaction to flake size; the knapper identified a flake big enough to make an LCT on, but which was too thick or possibly the wrong shape. However, there was a dorsal-ventral angle on one margin which would allow for the detachment of a suitable sized janus flake from the ventral. The result is the Kombewa flake-spall.

If the infrequency of Kombewa flake-cores is anything to go by, then this was not an important blank making technique. Sharon (2009) noted their infrequency at other Acheulean sites also. There are six Kombewa flake-cores in all and three flake-spalls. The technique is present in each sedimentary unit. The mean length for the preferential scars on all six Kombewa flake-cores was $121.5 \mathrm{~mm}$; the mean length for the Kombewa flake-spalls was $121 \mathrm{~mm}$ - small by comparison with cleavers.

\section{SIMPLE PREPARED CORES}

Just as with Kombewa, these are cores that are also conceptually PCT (White \& Ashton 2003). They have a hierarchically perceived preferential flaking face. On these cores more than one flake is detached, all parallel to a fixed margin. In this sense they conform to part of Böeda's concept of Levallois (Boëda 1995). However unlike PCT cores, the fixed margin/perimeter is not carefully maintained, and the flaking face is not shaped. They have been described as a 'stripped down' Levallois by White and Ashton (ibid.). Only two simple prepared cores were identified in the whole sequence. There are undoubtedly more, but White and Ashton's article was published after substantial portions of the data had already been recorded. One of them is in Unit $2 \mathrm{~b}$ Lower. Given the total lack of evidence for any PCT in this unit it is likely that this particular core bears a fortuitous resemblance to simple prepared cores. The only other example is from Unit $2 \mathrm{a}$ in Area 2. No doubt that they are present in greater numbers in Unit $2 \mathrm{a}$, but they were not recognised at the time. It is significant that they have been independently identified at another Acheulean site in the Rietputs Formation, at Rietputs 15, by George Leader (pers. comm.). He describes them as 'organised cores', and he has also identified them in renewed excavations in Unit $2 \mathrm{a}$, pit 6 , at Canteen Koppie. Levallois and Victoria West are not present in the undisturbed Acheulean layers at the Cave of Hearths. 


\section{DISCUSSION AND CONCLUSIONS}

Canteen Koppie is a key site. Its lower units may well be older than the Middle Pleistocene, but this remains to be established. A dating programme on the Canteen sediments is a research priority of the highest importance.

The site reflects a consistently uniform Acheulean signal throughout more than $8 \mathrm{~m}$ of accumulated sediment. At this one site Acheulean hominins did the same thing for a very long time. In terms of making stone tools at least, hominins were probably drawn to this location by the presence of the andesite boulders, occasionally replenished along the river's bank. The site may have been a fixed point in the hominin landscape, a factory location where one activity dominated - making the blanks for cleavers and handaxes. The lack of any diachronic development in the individual categories of Acheulean material culture is an interesting insight into the evolution (or lack of it) of the Acheulean. We know of no other sequence in southern Africa which preserves this depth of stratigraphy, with the possible exception of the later Acheulean site of Kalambo Falls. However this Zambian site only retains evidence of the late/final Acheulean (Clark 2001). Dating the sediments at Canteen will be important in this respect since the Acheulean package arrived already fully formed at the site. So where ever it originated, it did so prior to the age of the basal sediments in Area 1.

However, if the Acheulean did not significantly change over time, then the addition of the Victoria West and Levallois in Unit 2a clearly shows that new ideas and practices occurred over the time span of this sedimentary unit. No evidence for in situ development of these technologies is present at the site. Van Riet Lowe made it abundantly clear (Van Riet Lowe 1945; 1954) that he believed the Victoria West was a part of the Acheulean, effectively a technology practiced by handaxe makers. Given the range of conditions that both LCTs and Victoria West occur in, the data from Canteen Koppie more than confirms their contemporaneity, and the size data that supports the use of Victoria West flakes as LCT blanks is equally suggestive. Moreover, Lycett and colleagues (Lycett 2009; 2010) have argued that a morphological study of the surface of Victoria West cores, when compared with surfaces of handaxes and Levallois cores, suggests that the former are an independent Acheulean invention, and that true Levallois is a distinct phenomenon with a discreet origin. Lycett (ibid.) prefers the term para-Levallois to indicate a conceptual similarity without implying an evolutionary relationship between Victoria West and the Levallois. Canteen contributes directly to this origins debate.

The contemporaneity between Victoria West, PCT, and the Acheulean at Canteen Koppie demonstrates that a simple unilinear cultural evolution from the Acheulean into the Levallois via early examples of PCT-like technology cannot be supported. This pattern has been repeated in other parts of Africa. Sites in the Kapthurin Formation in Kenya, dated to $>285$ kya (Tryon \& McBrearty 2002), and in the Sudan (Van Peer et al. 2003), dated at about 200 kya, show the inter-stratification of MSA and Acheulean assemblages, indicating the broad contemporaneity of Levallois with older ESA technologies. Canteen is similar in this respect. The co-occurrence of worn and fresh Levallois and Acheulean artefacts throughout a fluvial gravel with a variable colluvial scree component (de Wit 2008), which accumulated over time, supports a similar contemporaneity. But geological contemporaneity does not necessarily imply absolute contemporaneity on a hominin timescale. Were the Acheulean knappers also responsible for making the convergent points and the blades sensu Lycett? Unfortunately the scale of resolution necessary to answer that question is not present at Canteen Koppie. One thing the site can support is the observation made by other researchers elsewhere, namely, the production of blades is not wholly restricted to modern humans and their immediate ancestors. The roots of some of the material culture more commonly associated with modern humans, and the behavioural patterns that would accompany them, are considerably older than previously assumed.

\section{BIBLIOGRAPHY}

Ashton, N., Dean, P. \& McNabb, J. 1991. Flaked flakes: what, where, when and why? Lithics 12, 1-11

Barham, L. 2010. A technological fix for 'Dunbar's dilemma'? In R. Dunbar, C. Gamble \& J. Gowlett (eds), Social Brain, Distributed Mind, 367-89. Oxford: University Press

Barkai, R. 2009. Comment on Sharon. Current Anthropology 50, 356-7

Beaumont, P. 1990. Canteen Koppie. In Beaumont \& Morris (eds) 1990, 14-7 


\section{THE PREHISTORIC SOCIETY}

Beaumont, P. 1999a. Canteen Koppie, Barkly West. In Beaumont (ed.) 1999b, pages un-numbered

Beaumont, P. (ed.). 1999b. Inqua $x v$ International Conference Field Guide: Northern Cape. Pretoria: Institute of Geosciences

Beaumont, P. 2004. Canteen Kopje. In Morris \& Beaumont (eds) 2004, 26-30

Beaumont, P. \& Morris, D. (eds). 1990. Guide to the Archaeological Sites in the Northern Cape. Excursion Guide to the South African Association of Archaeologists, September 1990. Kimberley: McGregor Museum

Beaumont, P. \& Vogel, J. C. 2006. On a timescale for the past million years of human history in central South Africa. South African Journal of Science 102, 217-28

Boëda, E. 1995. Levallois: A volumetric construction, methods, a technique. In H. L. Dibble \& O. Bar-Yosef (eds), The Definition and Interpretation of Levallois Technology, 41-68. Madison, Wisconsin: Prehistory Press

Clark, J.D. 2001. Kalambo FallsPrehistoric Site. Volume 3: the earlier cultures: Middle and Earlier Stone Age. Cambridge: University Press

Foley, R.A. \& Lahr, M.M. 1997. Mode 3 technologies and the evolution of modern humans. Cambridge Archaeological Journal 7, 3-36

Forssman, T.R., Kuman, K., Leader, G.M. \& Gibbon, R.J. 2010. A Later Stone Age assemblage from Canteen Kopje, Northern Cape. South African Archaeological Bulletin 65, 204-14

Gibbon, R.J., Granger, D.E., Kuman, K. \& Partridge, T.C. 2009. Early Acheulean technology in the Vaal river gravels, South Africa, dated with cosmogenic nuclides. Journal of Human Evolution 56, 152-60

Goodwin, J. H. 1929. Part iii. The Victoria West industry. In Goodwin \& Van Riet Lowe (eds) 1929, 53-71

Goodwin, J. H. 1934. Some developments in technique during the Earlier Stone Age. Transactions of the Royal Society of South Africa 21, 109-23

Goodwin, J. H. \& Van Riet Lowe, C. 1929. The Stone Age cultures of South Africa. Annals of the South African Museum 27, 1-289

Harris, J.W.K., Braun, D.R. \& Pante, M. 2007. 2.7 myr-300,000 years ago in Africa. In S.A. Elias (ed), Encyclopedia of Quaternary Science, volume 1, 63-72. London: Elsevier

Helgren, D.M. 1978. Acheulean settlement along the lower Vaal river, South Africa. Journal of Archaeological Science 5, 39-60

Helgren, D.M. 1979. River of Diamonds: an alluvial history of the lower Vaal basin, South Africa. University of Chicago; Department of Geography Research Paper 185

Jansen, F.J. 1926. A new type of stone implement from Victoria West. South African Journal of Science 23, 818-25

Kuman, K. 1996. The Oldowan industry from Sterkfontein: raw materials and core forms. In G. Pwiti \& R. Soper (eds), Aspects of African Archaeology. Papers from the 10th Congress of the Pan-African Association for Prehistory and Related Studies, 139-46. Harare: University of Zimbabwe Publications
Kuman, K. 2001. An Acheulean factory site with prepared core technology near Taung, South Africa. South African Archaeological Bulletin 56, 8-22

Kuman, K. 2007. The Earlier Stone Age in southern Africa: Site context and the influence of cave studies. In $\mathrm{T}$. Pickering, K. Schick \& N. Toth (eds), Breathing Life into Fossils. Taphonomic Studies in Honour of C.K. (Bob) Brain, 181-98. Bloomington, Indianna: Stone Age Institute Press

Leakey, M.D. 1971. Olduvai Gorge: Excavations in Beds $i$ and ii 1960-1963. Cambridge: University Press

Lycett, S.J. 2009. Are Victoria West cores 'proto-Levallois'? A phylogenetic assessment. Journal of Human Evolution $56,175-91$

Lycett, S.J. 2010. A comparative 3D geometric morphometric analysis of the Victoria West cores: implications for the origins of Levallois technology. Journal of Archaeological Science 37, 1110-7

Machin, A. \& Mithen, S. 2004. Reply to McNabb et al. Current Anthropology 45, 668-9

Mason, R.J. 1959. Statistical analysis of South African later Chelles-Acheul and earlier Fauresmith cultures. Nature 183, 377-9

Mason, R.J. 1962. Prehistory of the Transvaal. Johannesburg: Witwatersrand University Press

Mason, R.J. 1988. Cave of Hearths, Makapansgat, Transvaal. Johannesburg: University of the Witwatersrand Archaeological Research Unit Occasional Paper 21

McBrearty, S. \& Brooks, A. 2000. The revolution that wasn't: A new interpretation of the origin of modern human behaviour. Journal of Human Evolution 39, 453-563

McNabb, J. 2001. The shape of things to come. A speculative essay on the role of the Victoria West phenomenon at Canteen Koppie, during the South African Earlier Stone Age. In S. Milliken, \& J. Cook (eds), A very Remote Period Indeed. Papers on the Palaeolithic Presented to Derek Roe, 37-46. Oxford: Oxbow Books

McNabb, J. 2009. The ESA stone tool assemblage from the Cave of Hearths, Beds 1-3. In McNabb \& Sinclair (eds) 2009, 75-94

McNabb, J. \& Beaumont, P. 2011. A Report on the Archaeological Assemblages from Excavations by Peter Beaumont at Canteen Koppie, Northern Cape, South Africa. Oxford: Archaeopress/University of Southampton Series in Archaeology 4

McNabb, J., Binyon, F. \& Hazelwood, L. 2004. The large cutting tools from the South African Acheulean and the question of social traditions. Current Anthropology 45, 653-68

McNabb, J. \& Sinclair, A. (eds). 2009. The Cave of Hearths: Makapan Middle Pleistocene Research Project: field research by Anthony Sinclair and Patrick Quinney 1996-2001. Oxford: Archaeopress/University of Southampton Series in Archaeology 1

Morris, D. \& Beaumont, P. (eds). 2004. Archaeology in the Northern Cape: some key sites. Guidebook Prepared for the Southern African Association of Archaeologists PostConference Excursion, 8-10 April 2004. Kimberley: McGregor Museum 
J. McNabb \& P. Beaumont. ACHEUlEAN LEVELS AT EARLIER STONE AGE CANTEEN KOPPIE, NORTHERN PROVINCE, S. AFriCA

Partridge, T.C. \& Brink, A.B.A. 1967. Gravels and terraces of the lower Vaal river basin. South African Geographical Journal 49, 23-38

Rolland, N. 1986. Recent findings from La Micoque and other sites in south-western and Mediterranean France: their bearing on the 'Tyacian' problem and Middle Palaeolithic emergence. In G.N. Bailey \& P. Callow (eds), Stone Age Prehistory, 121-51. Cambridge: University Press

Rolland, N. 1995. Levallois technique emergence; single or multiple? A review of the Euro-African record. In H. L. Dibble \& O. Bar-Yosef (eds), The Definition and Interpretation of Levallois Technology, 333-59. Madison, Wisconsin: Prehistory Press

Semaw, S., Rogers, M. \& Stout, D. 2009. The OldowanAcheulean transition: Is there a 'Developed Oldowan' artefact tradition? In M. Camps \& P. R. Chauhan (eds), Sourcebook of Paleolithic Transitions, 172-93. London: Springer

Sharon, G. 2007. Acheulean Large Flake Industries. Technology, Chronology, and Significance. Oxford: British Archaeological Report S1701

Sharon, G. 2008. The impact of raw material on Acheulean large flake production. Journal of Archaeological Science $35,1329-44$

Sharon, G. 2009. Acheulean giant-core technology. Current Anthropology 50, 335-67

Sharon, G. \& Beaumont, P. 2006. Victoria West: A highly standardized prepared core technology. In N. Goren-Inbar \& G. Sharon (eds), Axe Age. Acheulian Tool Making from Quarry to Discard, 181-99. London: Equinox

Söhnge, P.G., Visser, D.J.L. \& Van Riet Lowe, C. (eds). 1937. The Geology and Archaeology of the Vaal River Basin. Cape Town: Geological Survey
Thornes, J. 1979. River Channels. London: Macmillan Education

Tryon, C.A. \& McBrearty, S. 2002. Tephrostratigraphy and the Acheulean to Middle Stone Age transition in the Kapthurin Formation, Baringo, Kenya. Journal of Human Evolution 42, 211-35

Van Peer, P., Fullagar, R., Stokes, S., Bailey, R.M., Moeyersons, J., Steenhoudt, F., Geerts, A., Vanderbeken, T., De Dapper, M. \& Geus, F. 2003. The Early to Middle Stone Age transition and the emergence of modern human behaviour at site 8-b-11, Sai island, Sudan. Journal of Human Evolution 45, 187-93

Van Riet Lowe, C. 1935. Implementiferous gravels of the Vaal river at Riverview estates. Nature 136, 53-5

Van Riet Lowe, C. 1937. Part ii. The archaeology of the Vaal river basin. In Sohnge et al. (eds) 1937, 61-131

Van Riet Lowe, C. 1945. The evolution of the Levallois technique in South Africa. Man 45, 49-59

Van Riet Lowe, C. 1952. The Vaal river chronology. South African Archaeological Bulletin 7, 135-49

Van Riet Lowe, C. 1954. A note on Prehistoric classification. Man 54, 83-4

Wadley, L. \& McNabb, J. 2009. Introduction. In McNabb \& Sinclair (eds) 2009, 1-11

White, M.J. \& Ashton, N. 2003. Lower Palaeolithic core technology and the origins of the Levallois method in north-western Europe. Current Anthropology 44, 598-609

Wit, M.C.J. de 2008. Canteen Koppie at Barkly West: South Africa's first diamond mine. South African Journal of Geology 111, 53-66 
